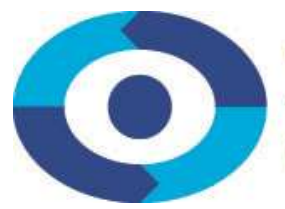

\title{
The panorama for Vietnam's Timber Industry with Vietnam-EU Free Trade Agreement (EVFTA): Opportunities and challenges
}

\author{
Ha Cong Anh Bao \\ Foreign Trade University (FTU), Vietnam \\ Baohca@ftu.edu
}

This study aims to identify and analysing both advantages and disadvantages of the EVFTA to Vietnam's timber industry, based on the main research question: To what extent is Vietnam's Timber industry affected by VEFTA? The author's hypothesis is that VEFTA will positively impact to boost the import and export activities of Vietnam timber industry. This hypothesis is clarified based on the analysis of tax SMART/WITS model in comparison with other competitors exporting timber to the EU market such as Indonesia, China, Malaysia, Thailand and Brazil; combined with an analysis of the actual import - export of Vietnam's timber industry to the EU market based on the secondary data from The World bank, ITCand primary data by interviewing specialists and local furniture exporters to the EU market.

Research for this paper was funded by the Swiss State Secretariat for Economic Affairs under the SECO / WTI Academic Cooperation Project, based at the World Trade Institute of the University of Bern, Switzerland.

SECO working papers are preliminary documents posted on the WTI website (www.wti.org) and widely circulated to stimulate discussion and critical comment. These papers have not been formally edited. Citations should refer to a "SECO / WTI Academic Cooperation Project" paper with appropriate reference made to the author(s). 


\section{Content}

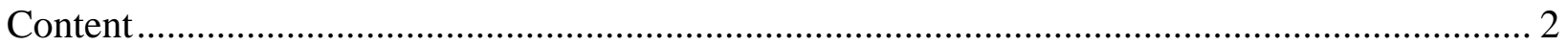

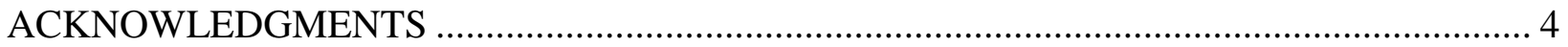

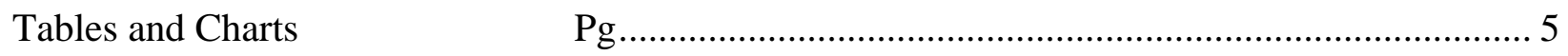

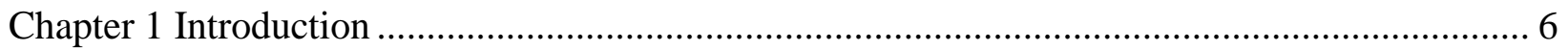

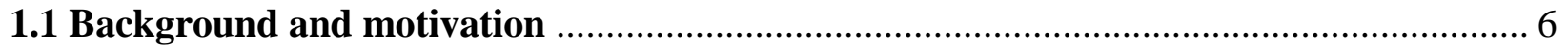

1.2 Research purpose, Objectives and questions ................................................................... 7

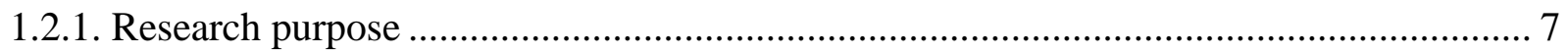

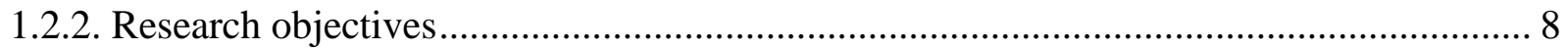

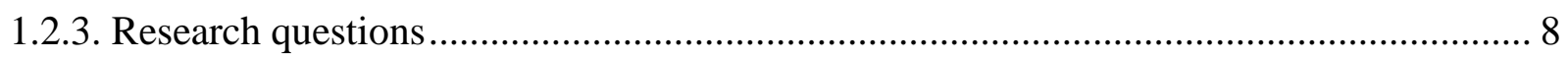

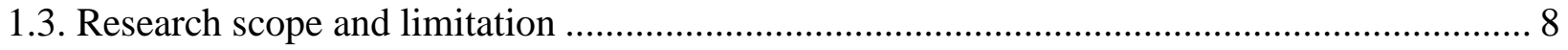

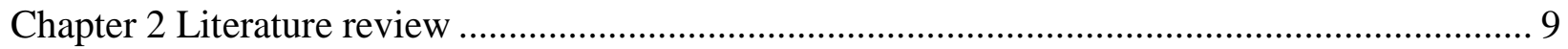

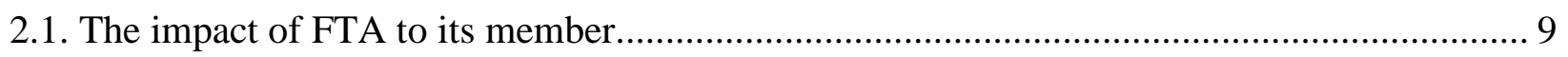

2.2. Factors affecting to import and export activities ………..................................................... 10

Chapter 3: The Process of negotiating the EVFTA and its role to member countries.................. 13

3.1. General view of the Vietnam-EU Free Trade Agreement ................................................... 13

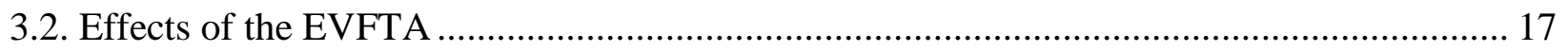

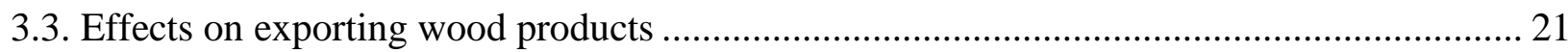

Chapter 4. Overview of Vietnam's timber industry and EU timber market.................................. 25

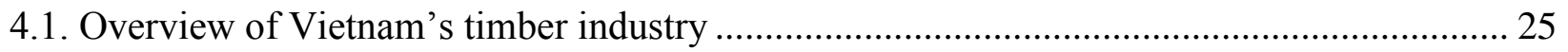

Source: Report on "Helping Associations conduct a research on strategies to develop Wood

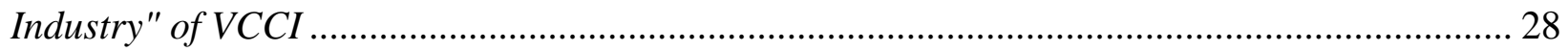

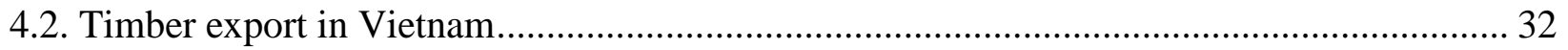

4.3. Timber export and import activities between Vietnam and EU .......................................... 34

Source: Data from Report on "Helping Associations conduct a research on strategies to develop

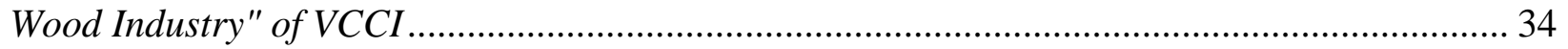

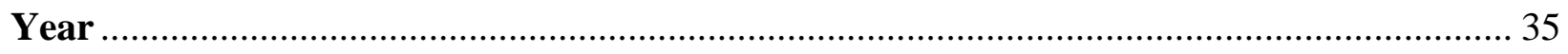

Source: Data from Report on "Helping Associations conduct a research on strategies to develop

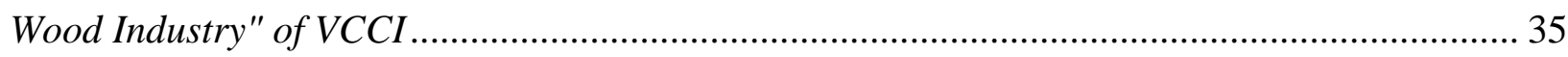

4.4. The requirements to export timber product to the EU market and the factors affecting

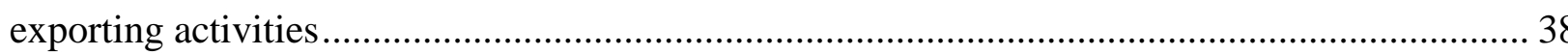


Quality standards: Timber products used for construction have to satisfy requirements relating to: Durability; Environment protection; Health and hygiene; Safety; Noise absorption; Energy saving; Heat preservation. .......................................................... 42

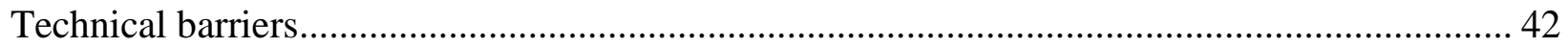

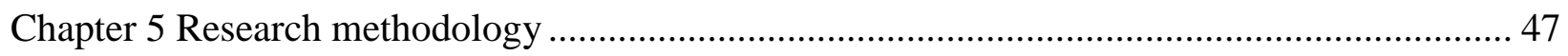

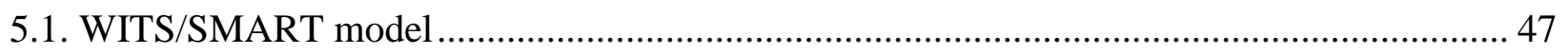

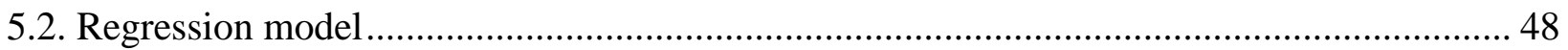

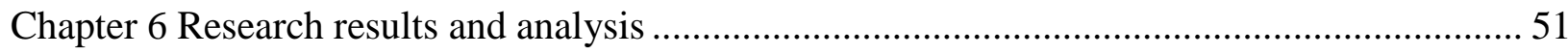

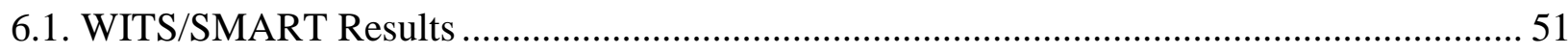

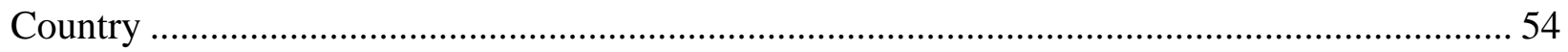

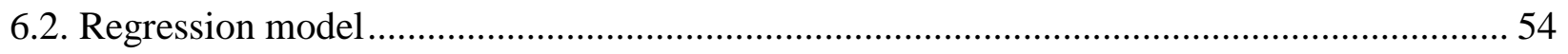

Source: Results from handling survey data with SPSS .................................................... 55

Exploratory Factor Analysis: Factor analysis is used only when the KMO coefficient

[Kaiser - Meyer - Olkin] is greater than 0.5. The factor loading which is less than 0.5 will be rejected, stops when Initial Eigenvalue is greater than 1 and the scale is accepted as the total variance is equal to or greater than 0.5. (Hoang Trong and Mong Ngoc, 2005)................ 55

Factors affecting Export exporting activities: Step-wise linear regression model was used to choose variables with great impacts of service quality of VNPT $3 \mathrm{G}$ service. Probability of statistics is a standard variable to be used in the model $\mathrm{F} \leq 0.05$ (Probability of $\mathrm{F}-$ to - enter). Standard to take a variable from the model is that probability of statistics $\mathrm{F} \geq 0.10$............ 57

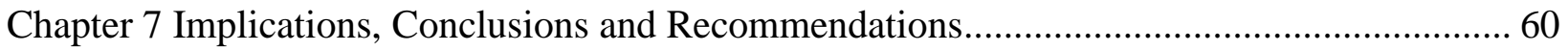

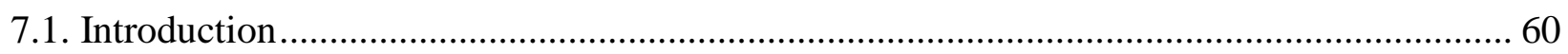

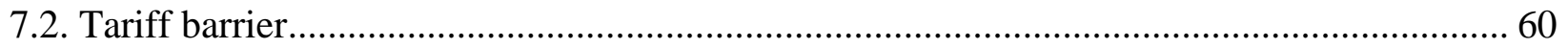

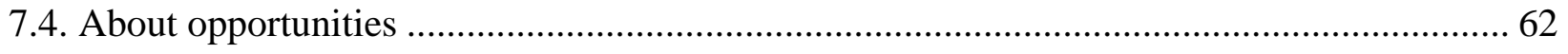

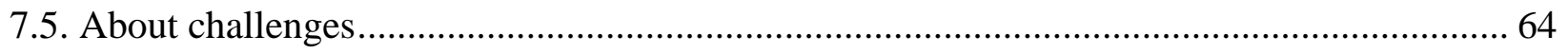

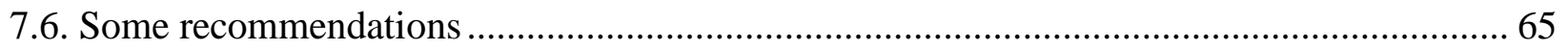

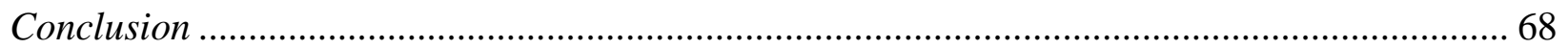

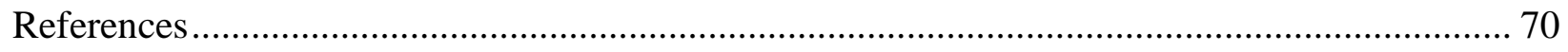

Annex 1: Technical Description of the UNCTAD Trade Policy Simulation Model................... 75

Annex 2: Some examples of Eu non-tariff barriers applied for wood product (HS 44; 94)........ 80 


\section{ACKNOWLEDGMENTS}

From my heart, I would like to show my gratitude and sincere thanks to Dr Christian Häberli, from World Trade Institute, Switzerland, who is my mentor, for guiding me to find out research, practical approach, looking for material, processing and data analysis, solving problem ... so that I can complete my research.

Also, in the process of learning, researching and implementing the research I was getting a lot of attention, suggestions, supporting from my precious colleagues, expertise and organizations. I would like to express deep gratitude to:

SECO and FTU which supporting finance to complete the research.

Mr Nguyen Van Tuyen, Director of Tien Dat Company, for his advisements.

All members of my wonderful research team: Ms Quynh Yen, Ms. My Hanh, Ms Phung Yen and Mr Ngoc Ha who have worked by heart to collect the data, interview the experts and logistics to help me finish the research. 
Tables and Charts

Chart 4.1 the number of timber processing companies in Vietnam over the past few years 24 Chart 4.2: Timber industry's workforce proportion in 2013

Chart 4.3 Forecast of total demand for timber manufacturing materials and the supplies 26

Chart 4.4: Wood area (thousand hectares) and exploiting quantity (cubic meter) from 200927 to 2013

Chart 4.5: Timber exports turnover in Vietnam from 2006 to 2014

Chart 4.6: Export market of timber and timber products of Vietnam in 2013

Chart 4.7: The turnover of timber export to the EU v. the total turnover of timber export of 32 Vietnam from 2009 to 2014

Chart 4.8: EU 28 import of wood furniture from other suppliers by country - years 2004- 34 2014 (except China)

Chart 4.9: Tropical Glulam import amount in the EU by market from 2012 to 2014

Chart 4.10: Tropical timber flooring import amount in the EU by market from 2012 to 2014

Table

Table 4.1: Timber materials import markets of Vietnam in 2013

Table 4.2. Turnover of furniture export from Vietnam compared with total turnover of 33 furniture import in $\mathrm{EU}$

Table 5.1 Model research $\quad 48$

Table 6.1.SMART simulation results in Scenario 1: The impact of the FTA on Vietnam's 49 wood exports into EU market

Table 6.2.SMART simulation results in Scenario1: The impact of the FTA on EU's wood 50 exports into Vietnam market

Table 6.3. Synthesis simulation results of the SMART model: Forecasting the impact of the 52 FTA on countries' exports to the EU

Table 6.4 Cronbach's alpha results $\quad 53$

Table 6.5. KMO and Bartlett's Test $\quad 54$

Table 6.6 Rotated Component Matrix ${ }^{\mathrm{a}} \quad 54$

Table 6.7. Coefficients ${ }^{\mathrm{a}} \quad 56$

Table 6.8. R Square $\quad 57$

Table 6.9. Test the suitability of the regression model ANOVA ${ }^{\mathrm{b}} 57$

Table 7.1. Statistics Mean of Environmental Barrier $\quad 60$

$\begin{array}{ll}\text { Table 7.2. Statistics Mean of Internal problem } & 60\end{array}$ 


\title{
The panorama for Vietnam's Timber Industry with Vietnam-EU Free Trade Agreement (EVFTA): Opportunities and challenges
}

\author{
Ha Cong Anh Bao ${ }^{1}$
}

\section{Chapter 1 Introduction}

\subsection{Background and motivation}

According to statistics in recent years, Vietnam's total exports and imports turnover with European countries reached USD 46.633 million in 2014, increased by nearly $20 \%$ as compared to $2013 .^{2}$ The European Union (EU) has been the second largest furniture importer of Vietnam after the United States (My Chau, 2013).The EU-Vietnam economic and trade relation has become increasing corporation after Vietnam signed the EU-VN Free Trade Agreement (EVFTA). The execution of this agreement will have a significant influence on Vietnam's economy in general and Vietnam's timber industry in general, both positively and negatively. On the one hand, the EVFTA is considered to bring important advantages to Vietnam's timber industry (WTO Ho Chi Minh Center, 2014), ${ }^{3}$ some visible benefits from the EVFTA are the $0 \%$ tax rate on timber products ${ }^{4}$, more EU investors attracted to Vietnam, thus helping the country to raise its role and position in the global wood market and yield an increase in general output as well as enhance national competitive advantage. In addition, the free trade agreements that Vietnam has been signed as a free trade agreement: Korea - Vietnam, Vietnam - Japan, Vietnam Chile, Vietnam - Eurasian economic Union ... and especially Trans-Pacific Partnership Agreement were signed 12 member countries in 2015 will bring more opportunities for investors.

\footnotetext{
${ }^{1}$ Foreign Trade Univesity, Vietnam

2: www.trademap.org

${ }^{3}$ http://www.hoinhap.org.vn/tin-tuc/tin-trong-nuoc/6308-fta-viet-nam-eu-mang-lai-nhieu-loi-ich-cho-doanh-nghiepviet.html, Accessed on 12/11/2015

${ }^{4}$ Some timber product now is applied tax rate from $3-5 \%$
} 
On the other hand, as Vietnam being a member state of the VEFTA, Vietnam's timber industry will face a number of challenges in the process of expanding the market share. It has to compete with many big companies from other FTA's member countries. At the same time, it has to overcome heavy pressures from technical barriers, safeguard measures, antidumping and countervailing duties, intellectual property rights and geographical indications for domestic products, as well as enforcement of environmental and labour laws in a complete and effective manner to penetrate the EU market.

Therefore, this study aims to identify and analysing both advantages and disadvantages of the EVFTA to Vietnam's timber industry. Based on the main research question: To what extent is Vietnam's Timber industry affected by VEFTA? and the hypothesis: VEFTA will positively impact to boost the import and export activities of Vietnam timber industry. This hypothesis will be clarified based on the analysis of tax SMART/WITS model in comparison with other competitors exporting timber to the EU market such as Indonesia, China, Malaysia, Thailand and Brazil ${ }^{5}$; combined with an analysis of the actual import - export of Vietnam's timber industry to the EU market based on the secondary data from The World bank, ITCand primary data by interviewing specialists and local furniture exporters to the EU market.

\subsection{Research purpose, Objectives and questions}

\subsubsection{Research purpose}

On the basis of clarifying theoretical and practical matters of the timber industry, legal aspect, as well as making predictions about the opportunities and challenges of Vietnam's timber industry if free trade agreements Vietnam - EU (VEFTA) was signed, the research proposes solutions and recommendations to Vietnamese enterprises and the State to boost exports and import activities between Vietnam-EU after signing the EVFTA.

\footnotetext{
${ }^{5}$ Which countries are the most export timber into EU market, "Report from Europe" of Global Wood: http://www.globalwood.org/market/timber_prices_2015/aaw20150202e.htm, Accessed on 12/11/2015
} 


\subsubsection{Research objectives}

This research is implemented to achieve four following objectives:

- To review the relevant literature of the research topic.

- To analysis of the actual state of the timber industry in Vietnam in general and the import - export situation of Vietnam's timber industry to the EU market in particular;

- To assess and predict the effects of FTA Vietnam - EU to Vietnam's timber industry;

- Propose solutions and recommendations for Enterprises and State to boost the import and export activities of the timber industry between Vietnam and EU.

\subsubsection{Research questions}

The objective of this research is to propose solutions and recommendations to Vietnamese Enterprises and State to boost exports and import activities between Vietnam and due after signing the FTA. In order to meet this objective, this study focuses on the main research question: To what extent is Vietnam's Timber industry affected by VEFTA?

\section{Main Research Hypothesis:}

VEFTA will positively impact to boost the import and export activities of timber industry between Vietnam and EU. To answering the above research question, the author conducted investigation and analysis of responses of both Vietnamese Timber enterprises and some experts towards the effect of EVFTA on the timber industry.

\subsection{Research scope and limitation}

Due to the lack of time and the limited number of respondents of the surveyed questionnaire, so this research would encounter certain difficulties with regard to reliability and representativeness of the survey's result.

The scope of this research includes:

- Subjects of study: The tariff and non-tariff measures affecting import and export activities of timber products between Vietnam and the EU. 
- Survey scope: Vietnamese Timber Enterprises who have already been importing from and exporting to the EU market.

- Location: Hanoi City, Dak Lak province, Nghe An province, Ho Chi Minh City.

\section{Chapter 2 Literature review}

\subsection{The impact of FTA to its member}

The rapid expansion of Free trade agreement (FTA) has been one of recent phenomenal developments in the world economy (Chan-Hyun Sohn and Hongshik Lee, 2005). Free Trade Agreements (FTAs) aims to reduce or eliminate trade barriers between the parties to the FTAs, and thus increase trade between them (Titus Lee, Tan Kok Kong, 2011).A large amount of research on effects of FTA to parties' economies or to each field of them has been conducted. According to Ganeshan Wignaraja (2010), Thai trade negotiators have striven to secure market access via FTAs, but little is known on how FTAs actually affect exporting firms. The result of an investigation among 221 Thai exporters shows that most companies recognized the effects of FTAs to their businesses; however, they did not seem to have high awareness of the FTA's full content. This fact leads to a highly recommendation in which FTA should be disseminated better to companies. The result of Titus Lee's research (2011) reveals that FTAs has a positive effect to the economy of Singapore. FTAs have given rise not only to a substantial level of actual tariff savings, but also to an increase in the demand for exports originating from Singapore that is distinct from other factors such as GDP growth and exchange rate movements.

In order to evaluate the general effect of the FTA among USA and Marco, Mustapha Sadi Jallab and partners (2007) have used the WITS/SMART Model, as any partial equilibrium model, these strong assumptions only allow trade policy analysis to be undertaken at one country at a time. In spite of this weakness, WITS/SMART can help estimate trade creation, diversion, welfare and revenue effects, and the results show that the various modalities of trade liberalization may have different impacts on the welfare, the rate of growth and the sectoral trade balance of these two countries. 
On evaluating effect of FTAs schemes on the scales of companies, the research of Kazunobu Hayakaww (2012) shows that the scale of a company can only be influenced by FTAs scheme in respect of exporting, not importing. Therefore, they suggested that they should assist firms to use FTA schemes in exporting even if they were already using FTA schemes in importing.

In general, there are many methods and models which can be used to evaluate effects of FTA to the member states. However, this study will adopt two main approaches, which are analysing the use of FTAs - records of official FTA certificates of origin and firmsurveys (Lili Yan Ing, Shujiro Urata, Yoshifumi Fukunaga, 2015).

Based on preceding results, this research will combine the two main approaches mentioned above including evaluating and analysing secondary data and data from companies' surveys in order to complete an entire evaluation of FTA's effects to Vietnamese timber industry

\subsection{Factors affecting to import and export activities}

There are many factors affecting companies' export and import activities, however, only some specific factors relating to FTAs would be taken into consideration including tariff barriers, non-tariff barriers and companies' internal activities.

Tariff barriers: A tariff is a tax imposed on the import or export of goods ${ }^{6}$, it also alters the relative prices of products, and can protect uncompetitive companies and their overpriced products (Love, Patrick and Ralph Lattimore, 2009), Tariffs are the most common kind of barrier to trade; indeed, one of the purposes of the WTO is to enable Member countries to negotiate mutual tariff reductions. ${ }^{7}$ Tariff barriers include import tax, export tax, some kinds of domestic tax and in some special case, exporting companies could be imposed anti-dumping tax.

\footnotetext{
${ }^{6}$ With regard to the scope of general MFN treatment, GATT Article I includes "customs duties and charges of any kind imposed on or in connection with importation or exportation . . . " and thus it deals with not only tariffs on importation but also those on exportation.

${ }^{7}$ Chapter 4: tariff, http://www.meti.go.jp/english/report/data/gCT9904e.html, Accessed on 12/11/2015
} 
Non-tariff Measures are non-tax measures imposed by governments to favour domestic over foreign suppliers. Non-tariff Measures have similar effects to tariff barriers. They increase domestic prices and impede trade to protect selected producers at the expense of domestic consumers (Cleins C. Coughlin and Geoffrey E. Wood, 1989). Today, with the dominance of global value chains and the increased tradability of nontangible products, we are confronted with new and important questions about the impact of NTMs on competitiveness and productivity ${ }^{8}$. The OCED report (2009) shows that developing countries rely heavily on exports to developed countries; the main non-tariff barriers include customs and administrative procedures and technical barriers (Love, Patrick and Ralph Lattimore, 2009, pg. 62).

Environmental barriers, social and labour standards, state trading, general governance and private corporate responsibility issues are also subjects of studies by many researchers while assessing impacts on export and import activities. These factors have been applied to FTA's new generation and mentioned by many authors. (For example: Disdier et al., 2008; Fontagne et al., 2005; Moenius, 2004; Cole and Elliott, 2005; Cole et al., 2010; Dean et al., 2009.Dirk Michael Boehe and Luciano Barin Cruz, 2009)

Furthermore, import and export activities are also under impact of the companies' internal factors such as: equipment, labour qualifications, resources,...(Yot Amornkitvikai et al., 2012; capital (David Greenaway et al. 2009); sale promotion (Jose R. Brenes et al., 1992); business strategy (Tulin Ural et al. 2006)

Generally, in recent researches, some specific factors have been studied to clarify theirs affects to companies' export and import activities, however, the whole direct impacts of these factors on their businesses have not been defined yet. Therefore, based on results of preceding studies, this research will assess the effects of all mentioned factors in the view of Vietnamese timber enterprises.

\footnotetext{
${ }^{8}$ PRONTO project, About Pronto, http://pronto.wti.org/the-project/ , Accessed on 07/05/2015
} 


\section{Chapter 3: The Process of negotiating the EVFTA and its role to member countries}

\subsection{General view of the Vietnam-EU Free Trade Agreement}

From 01.01.2014, Vietnam enjoyed the new Generalised System of Preferences (GSP) of the European Union for all commodities. Despite of the preferential tax rate for the tax line, the majority of tariffs on some key export items of Vietnam to the EU is still relatively high; for example textiles (11.7\%), fisheries (10.8\%), footwear (12.4\%) and so forth. GSP is also not granted permanent which is reviewed periodically. Besides GSP, EU also offers additional trade incentives to developing countries already benefitting from GSP to implement core international conventions on human and labour rights, sustainable development and good governance (GSP+). In 2014, the EU formally adopted GSP + (special preferential tax rates 1.5 times higher than GSP in any given time) for 10 developing countries. ${ }^{9}$ Those countries' export goods would be able to compete with those of Vietnam in the EU market.

Unlike GSP, EVFTA guarantees Vietnam free access to the EU market but apply the reciprocity regulation and forcing Vietnam to open their markets to EU imports.

After the 14th negotiating session taking place from 13 to 17 July 2015, on 04/8/2015, the Minister of Industry and Trade of Vietnam, Mr. Vu Huy Hoang and the EU Commerce Commissioner, Ms. Cecilia Malmström agreed in principle on finishing the negotiation of the Free Trade agreement between Vietnam and the European Union (EVFTA). EVFTA is expected to provide optimum benefits to people and enterprises of both parties.

In October 2010, the Prime Minister of Vietnam and the Chairman of the European Union (EU) agreed to start negotiations on FTA between Vietnam and the EU (EVFTA). On this basis, the two sides officially declared negotiations of EVFTA starting on June 26, 2012. In the spirit of positive negotiation of both the EU and Vietnam, with the care and guidance of the leaders of the two sides, negotiations were conducted in a rapid

\footnotetext{
${ }^{9}$ Evil Armenian -a, Bolivia, Latvia, Cape Verde, Costa-Rica, Egypt, cu-a-meter, a Georgia, Mongolia, Pa-raUruguay, Pa-ki-Pakistan and Peru
} 
progress. After nearly 3 years, with 14 main sessions and mid-term sessions, Vietnam and the EU officially agreed about all the basic content of the Agreement.

With the level of commitment achieved, EVFTA is acknowledged as a comprehensive, high quality agreement and ensures balanced benefits to both Vietnam and the EU (VCCI News, 2015).

\section{EVFTA includes 18 chapters with the following main contents:}

Trade of Goods: The EU commits to eliminate tariff barriers immediately when the EVFTA becomes effective to Vietnamese commodities concerning $85.6 \%$ of tax stream in tariff, equivalent to $70.3 \%$ of Vietnamese export turnover to the EU; Within 7 years counting from the effective date of EVFTA, the EU commits to eliminate $99.2 \%$ of tax stream in the tariff, equivalent to $99.7 \%$ of Vietnam's export turnover to the EU. In respect of $0.3 \%$ of remaining export turnover (including some rice products, sweet corn, garlic, mushroom and high-glucose products, tapioca and canned tuna), the EU undertakes to open up according to the tariff quotas (TRQs) at the rate duty within quotas of $0 \%$. Meanwhile, Vietnam undertakes to eliminate taxes immediately after the effective date of the EVFTA in respect of the EU's goods concerning $65 \%$ of tax stream in the tariff; Within 10 years from the effective date of the EVFTA, Vietnam commits to eliminate over $99 \%$ of tax stream in the tariff. The tariff quotas will be adapted to the remaining tax stream at the rate duty within quotas of $0 \%$.

Commitment on export taxes: Vietnam undertakes to eliminate most of export taxes in respect of exports to the EU and not to increase taxes in respect of the other products.

\section{Commitment on non-tariff measures:}

- Technique barriers to Trade (TBT) ${ }^{10}$ : Parties agreed to reinforce the rule of implementing process of the Agreement regarding of Technique barriers to Trade of WTO (the TBT) ${ }^{11}$, in which Vietnam undertakes to reinforce the use of international

\footnotetext{
${ }^{10}$ EVFTA, chapter 6

${ }^{11}$ EVFTA, chapter 6, Art 1.1: "The Parties reaffirm their existing rights and obligations with respect to each other under the WTO Agreement on Technical Barriers to Trade"
} 
standards in promulgating TBT rules. ${ }^{12}$ The Agreement contains 01 specific Appendix regarding non-tariff barriers to car industry, in which Vietnam undertakes to accept all Certificate of Conformity of car (COC) from EU after 5 years since the effective date of the EVFTA. Vietnam undertakes to accept label "Made in EU" on non-agricultural products (except for medicines), concurrently accept labels referring to a specific EU country.

- Sanitary and phytosanitary measures (SPS ${ }^{13}$ : Vietnam and EU have agreed on some principles regarding of SPS measures in order to facilitate commercial activities with respect of animal products and plant products. ${ }^{14}$ Particularly, Vietnam regards EU as a unity when reviewing SPS issues. ${ }^{15}$

- Other non-tariff measures: the Agreement also involves commitments considering a measure of decreasing other tariff barriers (for example: commitment on license for import/export, customs procedures... $)^{16}$ in order to facilitate import activities among the parties.

- Trade in services and investment: Commitment between Vietnam and the EU within the EVFTA regarding trade in services and investment aims to create an open investment environment facilitating business's activities between Vietnam and the EU's countries, in which ${ }^{17}$ : - Commitment of the EU in the EVFTA has higher validity than the commitment of the EU in WTO, ${ }^{18}$ equivalent to the highest level of the EU's commitment in recent FTAs - Commitment of Vietnam has higher validity than the

\footnotetext{
${ }^{12}$ EVTFA, Chapter 6, Art 4.1.b: the Parties agree to use relevant international standards, such as those developed by ISO, IEC, ITU, the Codex Alimentarius Commission, as a basis for their technical regulations ...

${ }^{13}$ EVFTA, Chapter 7

${ }^{14}$ EVFTA, Chapter 7, Art 2

${ }^{15}$ EVFTA, chapter 7: Technical Assistance and Special and Differential Treatment :Technical assistance should be provided to address specific needs of Viet Nam, to comply with sanitary and phytosanitary measure(s) regulated by EU Party including food safety, plant health and animal health, and the use of international standards.

${ }^{16}$ EVFTA, Chapter 3, chapter 5

${ }^{17}$ EVFTA, Chapter 8

${ }^{18}$ EVFTA, Chapter 8, Art 1.1: The Parties, reaffirming their respective commitments under the WTO Agreement and their commitment to create a better climate for the development of trade and investment between the Parties, hereby lay down the necessary arrangements for the progressive liberalisation of trade in services and investment and for cooperation on ecommerce.
} 
commitment of Vietnam in WTO, equivalent to at least the highest open-up level that Vietnam allows other partners in current FTA negotiations (including TPP) ${ }^{19}$;

- Government procurement: Vietnam reserves for a limited period the right to procure a certain rate of packages' value for bidders, goods, services and domestic workforce.

- Intellectual Property: the section of intellectual property in the EVFTA includes commitments on copyrights, inventions, patents, commitments related to pharmaceuticals and geographical indications with higher protection than those in WTO; however, this protection is basically coherent with the provisions of current laws of Vietnam. ${ }^{20}$ With timber product which will be affected by designing.

- State-owned enterprises and subsidiaries: the Parties agreed on principles in respect of state-owned enterprises; these principles along with the rules on subsidiaries aim to guarantee a fair competitive environment among state-owned enterprises and private enterprises when they engage in commercial activities.

- In respect of domestic subsidies: ${ }^{21}$ EVFTA allows a party grants the subsidies when they are necessary to achieve a public policy objective. ${ }^{22}$ One of a public policy objective is: promoting the economic development of areas where the standard of living is abnormally low or where there is serious underemployment, that regulations is legal basis for timber industry get the subsides that avoids EU trade remedies. EVFTA also introduces the principle of transparency and consultation procedures.

- Trade and sustainable development ${ }^{23}$ : The EVFTA contains a comprehensive chapter of trade and sustainable development, including some important provisions such as: Commitment to effective implementation of fundamental principles of the

\footnotetext{
${ }^{19}$ After 19 negotiation rounds, on 4/2/2016 TPP was officially signed at Ackland City, Australia. TPP consists of 30 chapters which adjusted trade and issues related to trade, starting with trade in goods and customs and trade facilitation; hygiene and animal and plant quarantine; technical barriers to trade; provisions on trade remedies; invest; service; ecommerce; Intellectual Property; labor; environment ... Besides adjusting the traditional content has been mentioned in previous FTAs, TPP was put into the new trade issues and emerging. These issues include the content of Internet and the digital economy, the growing involvement of state enterprises in trade and international investment, the ability of small businesses to take advantage of the trade agreements and other content.

${ }^{20}$ VCCI (2015), Summary of EVFTA, http://www.trungtamwto.vn/sites/default/files/tpp/attachments/ttwtotom_luoc_evfta.pdf, pg 9, Accessed on 12/11/2015

${ }^{21}$ EVFTA, Chapter 11: Competition policy

${ }^{22}$ The public policy objective list is regulated EVFTA, chapter 11, Section II Art x.1.2

${ }^{23}$ EVFTA, Chapter 15
} 
International Labour Organization (ILO), of ILO conventions (not only fundamental Conventions), of multilateral agreements on environment which each party has signed; Commitment not to decrease requests to or to prejudice the effective implementation of provisions regarding environment and domestic labour for the purpose of trade attractions and investment; Reinforcing the Corporate Social Responsibility (CRS) of enterprises with reference to international practices regarding this issue, a provision regarding climate changes and commitment to preservation and sustainable management of biodiversity (including wild flora and fauna), forests (including illegal logging), and fishing; The mechanisms to enhance civil society's participation in implementing these provisions, in both local view (consulting local advisory groups) and bilateral view (bilateral forums), provisions of enhancing transparency and accountability. Sustainable development is seen as the major challenges for Vietnam's export sectors including timber industry.

Dispute settling mechanism: The EVFTA sets up a settling disputes mechanism which may be raised between Vietnam and the EU while interpreting and implementing commitments within the Agreement. So that, this mechanism will be applied for the disputes occur when the Agreement takes effect. Recourse to the dispute settlement provisions of EVFTA shall be without prejudice to any action in the WTO framework, including dispute settlement action, or in any other international agreement to which both Parties are parties. ${ }^{24}$

\subsection{Effects of the EVFTA}

In general, experts have optimistic view of the EVFTA's influence on Vietnam's economy. According to Professor Claudio Dordi (2016), Technical Assistance Team Leader of the EU-MUTRAP, both Vietnam's exports to the EU and the reverse are faced with certain obstacles. However he still emphasized that when the EVFTA was signed, the benefits brought to Vietnam's economy seemed to outweigh the challenges posed by

\footnotetext{
${ }^{24}$ EVFTA, chapter 13 Art 24. Commitments on investment securities and dispute settlement is still currently in negotiation
} 
this agreement (Thanh Tam, 2015). Also, as to the effects of the EVFTA, an economic expert, Ms. Pham Chi Lan (2015) commented that the benefits from the EVFTA should be viewed from many different aspects, not just in the import-export balance. According other, after signing the EVFTA, even though Vietnam become the trade deficit country in the relation with the EU, this is also good because Vietnam can access to high-quality and sustainable sources of goods and services from the EU.

\subsubsection{Benefits:}

One of the most significant benefits relating to importing and exporting is that the powerful market access commitments in the EVFTA would be an important factor to promote the Vietnam-EU trade relation, which further expand exporting markets, especially the products in which the two sides having strengths, such as textiles, footwear, agricultural and fishery products, wood furniture from Vietnam and machinery and equipment, automobiles, motorcycles, beverages alcohol, a number of EU's agricultural products. Vietnam and the EU will eliminate import duties on $99 \%$ of tariff lines. For the few remaining tariff lines, both parties agreed to grant each other tariff quota or partial tariff reduction. This can be seen as the highest level of commitment that Vietnam has made in the FTAs which have been signed so far. Dr. Nguyen Thi Thu Trang (2015), Department of Legal, Vietnam Chamber of Commerce and Industry, indicated that on the EU usually commits to eliminate import tax for most of the their product lines and services in exchange for the corresponding level of commitment from partners. However, EU negotiators often insist on keeping tariff lines for agricultural products and fishery products. Therefore, the EU may either demand not too high with partners about opening respective agricultural markets, or accept concessions in other issues to offset this. Also, while the EU accepted opening its market immediately to partners, they often allow partners to have a relatively long schedule of tax reduction (i.e.10-12 years, sometimes up to 15 years). Obviously, from this perspective, the EU seems to be not a "tough" or "annoying" partner.

In the investment sector, the commitments in the EVFTA which ensure an open investment environment with more flexibility will help promote high quality investment 
flows of both the EU and other partners of Vietnam. The commitments related to investment, liberalization of trade in services, government procurement and intellectual property will also open up opportunities for both parties to access to their respective markets, ensure the overall balanced interests. On the other hand, the agreement also requires Vietnam to adjust some relating regulations. However, the adjustment is basically consistent with the policy of administrative reform of Vietnam and in the long run will bring positive effects to improve the system of relating regulations of the country.

Vietnam and the EU also agreed on the framework for cooperation programs and capacity building in areas of mutual concern. This framework will help Vietnam continue to build a stronger legal system, support the implementation of the commitments in the agreement, as well as enhance the competitiveness of small and medium enterprises. In order to increase commercial activities and bilateral investment based on mutual benefit.

Concerning the benefits of the EVFTA, EU Trade Commissioner, Ms.Cecilia Malmström said (2015): "Vietnam is a growing economy and once this agreement is up and running, it will provide significant new opportunities for companies on both sides, by increasing market access for goods and services". In her view, since over 31 million jobs in Europe depend on exports, having easier access to a growing and fast developing market like Vietnam, with its 90 million consumers, is great news. Besides, Vietnamese exporters will now get much easier access to the EU for their products, giving an important boost to Vietnam's economy. Both sides have worked extremely hard in the past few months to achieve this breakthrough.

The EU did not focus too much on the length of the portfolio on opening services market of partners, although they promote high level of openness. Instead, the EU focuses on strengthening the conditions for market entry and the service operation of EU providers in some specific service areas such as professional service (legal services, Accounting and auditing and bookkeeping services ...); Rental/Leasing Services without Operators; 
Advertising services, services incidental to agriculture, hunting and forestry. ${ }^{25}$ This may be an advantage for Vietnam while we are still relatively cautious in opening up services markets.

\subsection{2- Challenges of the EVFTA}

According to a MUTRAP's Report (2011) on the EVFTA, biggest non-tariff challenges affecting Vietnamese exports to the EU are connected to the EU's use of trade defence instruments, notably anti-dumping, and the EU's SPS and TBT measures. The Report states that "The EU is unlikely to make concessions on anti-dumping and countervailing duties to Vietnam and the FTA will probably not have any significant positive impact on the EU's resorting to anti-dumping and countervailing action against it - on the contrary, it might pose stricter requirements to Vietnam in the area of dumping, subsidization and the use of trade defence instruments", "As far as SPS and TBT measures are concerned, it seems improbable that a reduction of SPS and TBT barriers will take place. What is more probable is that the EU-Vietnam FTA will provide a framework for technical assistance, discussion and further co-operation on SPS and TBT issues”. In view of enterprises, Mr. Vu Truong Xuan (2015), Chairman of Vinabic Jsc approved that exporting skills and market adaption of local exporters is very limited, while the understanding of partners and market is crucial to the success of the business. As a matter of fact, the practical information on technical and environmental standards in the EU countries are very strict and difficult to access. Also, in order to provide suitable products for the EU market, enterprises must know the tastes of consumers. In general, this is a difficult for domestic enterprises. In the same point of view, Tran Dinh Van, CEO of Vision Challenge 360 also emphasized that specific information of EU partners were the leading concerns of domestic enterprises when joining the EVFTA (Tran Dinh Van, 2014).

Also, the majority of small and medium-sized enterprises in Vietnam, due to economic and financial difficulties, has little attention on administration and run their businesses mostly based on their experiences. Some enterprises have little concern about

${ }^{25}$ EVFTA, Chapter 8 Trade in Services, Investment and E-Commerce, Annex 8-c and Annex 8-d 
the non-tariff measures, typically barriers on vegetables and fruits, in the years of 20122013, there were 6 fruit shipments of Vietnam (5 lots of dragon fruit, 1 lot of rambutan) rejected by the US due to pesticide residues (Thanh Thanh, 2014). For the EU, there were also shipments of fruit unsuitable for exporting regarding to EU regulations. Similarly for fishery products, the main import markets like the US, EU are making stringent phytosanitary regulations (SPS) and environmental clauses (TBT). Typically there were Agricultural Act 2014 of the United States, and the EU's standards for residues of prohibited substances and restricted substances applied on in fisheries.

Regarding to issues of intellectual property, the protection of intellectual property in EU's FTAs do not always have higher requirements than that in WTO in every products. They only focus on the fields in which the EU has strength such as copyright, designs and geographical indications for wines, ham, cheese, timber products and so forth, these requirements are probably not too high for Vietnam.

\subsection{Effects on exporting wood products}

Being considered as one of the most important export products of Vietnam, wood and wood products also are significantly influenced by the EVFTA. There have been many opinions of experts predicting the panorama of wood products between EU-VN market.

- Benefits: According to Mr. Nguyen Ton Quyen (2014), Deputy Chairman, General Secretary of the Vietnam Wood and Forestry Products Association, EVFTA will bring a lot benefits for Vietnamese timber enterprises. Firstly, Vietnamese timber enterprises now mainly sell their products, they barely purchase foreign wood, but after signing the FTA, domestic enterprises will also have demand of buying wood from foreign companies, because the woods from Germany, Finland, Denmark and Sweden have rather high quality. Secondly, Vietnamese enterprises will not have to spend money on surveys, assessment for certification of the origin of the woods. Thirdly, domestic companies can buy wood processing machines from Europe without having to pay customs duties. Another important benefit of the EVFTA is that Vietnamese export 
enterprises can improve their business administration since when foreign partners purchase their products, they will send their professionals to give technical guidelines.

According to Mr. Cao Chi Cong (2015), deputy director of the Directorate of Forestry (Ministry of Agriculture and Rural Development), the EVFTA is also the first step which helps Vietnam and the EU coming to the FLEAT-VPA (Forest Law Enforcement, Governance and Trade - Voluntary partnership Agreements ${ }^{26}$, and if Vietnam has the FLEGT-VPA with the European Union, the access to the EU market can be easier as exporters of wood and wood products with FLEGT do not need to adapt EU Regulation 995. Similar to the EU market, other markets such as the US, Japan and Australia which have adopted strict rules on legal wood sourcing will open wider for timber shipments of Vietnam based on their confidence in timber legality assurance system of Vietnam, established after the end of FLEGT-VPA negotiation with the European Union.

- Challenges with the FLEGT-VPA: The EU's FLEGT (Forest Law Enforcement, Governance and Trade) Action Plan was established in 2003, which aims to reduce illegal logging by strengthening sustainable and legal forest management, improving governance and promoting trade in legally produced timber. The FLEGT-VPA is the trade agreements signed between the EU and partner countries on exporting wood and wood products.

According to Ms. Nguyen Tuong Van (2015) - Director of the steering committee of FLEGT-VPA, the purpose of the FLEGT-VPA negotiations between Vietnam and the EU is to achieve a deal allowing wood processing companies from Vietnam to expand exports of timber and timber products into the EU market and increase their ability to adapt to the regulations of the EU Timber Regulation (EUTR) which has been effective since 2013. The main content of the agreement is that Vietnam would build Timber Legality Assurance System (TLAS) which include five main components, including

\footnotetext{
${ }^{26}$ VPA is a legally binding trade agreement between the European Union and a timber-producing country outside the EU. The purpose of a VPA is to ensure that timber and timber products exported to the EU come from legal sources
} 
timber legality definition; control of the supply chain; the compliance with the definition of legal timber of organizations and households; FLEGT licensing system and independent evaluation. Ms. Van emphasized that the biggest challenge in the process of negotiation was that our system of TLAS must meet the requirements under international regulations for checking the origin of the wood but not to make additional administrative procedures, causing difficulties for businesses. To do that, there should be the participation of the enterprises and associations in the negotiating process, so that they can contribute comments and improve their understanding of the commitment content.

While the date of signing the FLEGT-VPA is near, there are not many enterprises which have basic understanding of the FLEGT-VPA, and the enterprises which meet these requirements are even fewer. This can directly influence the future of exporting furniture to the EU of Vietnam. According to a survey, in April 2014 taken by the Center for Education and Development (CED), only 57\% of enterprises know about the FLEGTVPA, $75 \%$ of enterprises do not know the contents of the FLEGT-VPA. Especially, 73\% of these businesses are exporting wood products to the EU (Thanh Huyen, 2014).

Another problem which makes the FLEGT-VPA negotiations become difficult for enterprises and policy makers in Vietnam is that the EU timber regulation requires exporters of timber into the EU market must provide information about the origin of wood and wood products in the supply chain. However, most Vietnam enterprises have difficulty in providing proof of legal timber origin when purchasing wood. One of the reasons is due to the limited awareness of wood sellers, another is because of the lack of consensus on the requirements about proof of legal origin of the wood.

Ms. Ann Weddle, Chief Advisor - Project of Strengthening implementation of FLEGT - NEPCON Vietnam organization indicated that many enterprises in the EU require partners to prove legal origin of timber for complying with the EU regulations, so if the suppliers in Vietnam understand and meet these requirements of the FLEGT, they will have a more competitive advantage. She believes that Vietnamese companies can increase their revenue since they will have more professional production methods (Bich Ngoc-Chu Chinh, 2015). 
The EVFTA, along with the FLEGT-VPA may bring about additional difficulties for both the governmental agencies and exporters of timber and timber products to the EU. However, they also create opportunities that allow Vietnamese timber enterprises to expand their market share in the EU. 


\section{Chapter 4. Overview of Vietnam's timber industry and EU timber market}

\subsection{Overview of Vietnam's timber industry}

Timber industry is one of the most actively developing industries in Vietnam over the past few years. In 2014, the export turnover of wood products in Vietnam reached USD 6.23 billion, making this type of goods become one of the five products gaining the

highest export turnover of the year. ${ }^{27}$ Currently it is making a profound integration into the international market, which leads to the fact that a number of Vietnam's timber products have been available in approximately 120 countries and territories.

\subsubsection{The number of timber manufacturing and processing enterprises in Vietnam} is currently tending to decrease, especially small and medium companies.

Based on data of the research titled "Setting out the map of relating parties for FLEGT/VPA in Vietnam" (Forest Trend, Nov. 2011), from 2000 to 2009, the number of timber processing enterprises raised from 741 units in 2000 to 1,710 units in 2005 and 3,089 in 2009 (the average annual growth rate of 18\% per year). In 2013, the number of timber manufacturing companies reached 3,900 units. However, according to Mrs. To Kim Lien, Director of the Center of Education and Development (CED), up to 2014 the timber processing industry of Vietnam remained only 3,500 companies.

The statistics stated in report named "Timber processing industry project of Jun. 2013" of the Agriculture and Rural Development Ministry show that by workforce, the number of extra-small enterprises make up to $46 \%$, small units of $49 \%$, medium units of $1.7 \%$ and large units of $2.5 \%$. By capital resources, only $5 \%$ of the enterprises are political businesses, the $95 \%$ remaining belong to private properties, in which foreign direct investment (FDI) companies make up to $16 \%$.

\footnotetext{
${ }^{27}$ Business in Brief 12/5, http://english.vietnamnet.vn/fms/business/130360/business-in-brief-12-5.html, Accessed on 20.03.2016.
} 
Chart 4.1 the number of timber processing companies in Vietnam over the past few years

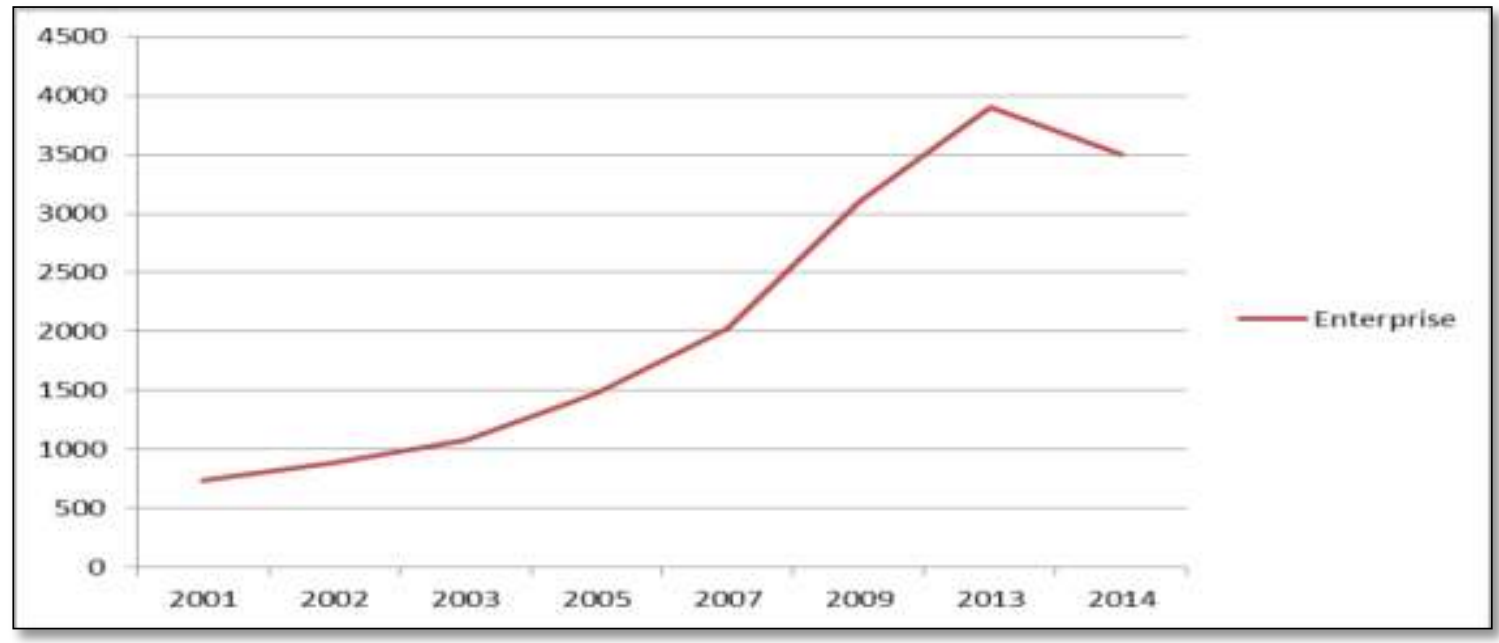

Source: Data from the research "Setting out the map of relating parties for FLEGT/VPA in Vietnam" of Forest Trend and the data from the Agriculture and Rural Development Ministry.

Particularly regarding FDI companies, large businesses stand at $30 \%$ of the total number, medium units take the rest. This figures can be used to explain the fact that despite of the FDI companies' low quantity proportion, they actually hold an important position in creating timber export turnover of Vietnam.

4.1.2. The industry attracts a great internal workforce; however, technical skills of the workers are rather low.

According to the Agriculture and Rural Development Ministry (2013), the timber industry attracted approximately 250,000 - 300,000 workers in 2013, however, the number of workers who are disciplined, trained for the job and able to work for long term is rather low, moreover, the division of labour is unclear as it does not mention weak management and observation.

This situation will actually affect the export orientation for products requiring high processing technology. These different figures can be explained by the specific features of the industry in which a large number of enterprises set up their businesses in the form of households, besides, a huge part of the workforce are seasonal. 


\section{Chart 4.2: Timber industry's workforce proportion in 2013}

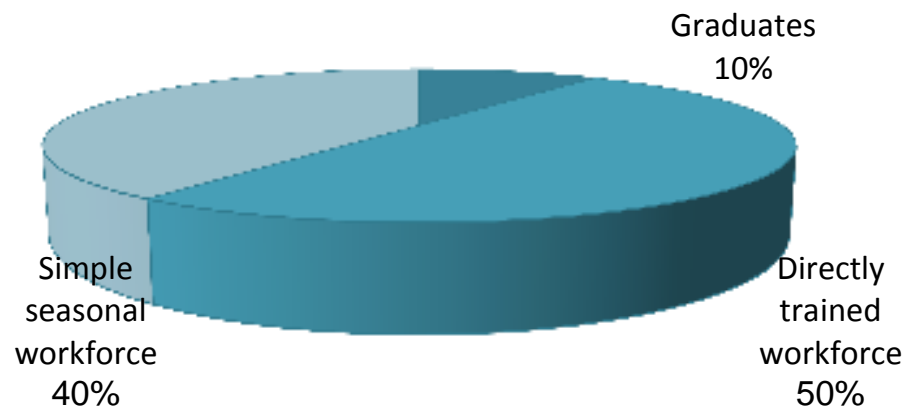

Source: Data from Report on "Helping Associations conduct a research on strategies to develop Wood Industry" of VCCI

\subsubsection{Science of technology is becoming more essential and well prepared in businesses}

Many Companies in Vietnam has been successful in providing solutions for improving the level of technology such as applying some types of machines which support workers in timber processing (e.g. splitting or drying technology) and creating artificial planks from planted woods which increases the productivity and reduces the expense of labour. Equipments are also improved to be suitable for the specific purposes (e.g. some splitting, mincing machines or desiccators are improved for using in processing planted woods of small sizes). Some modern technologies such as timber denaturation processing and composite wood making which currently starting to be developed in Vietnam. However, applying modern technologies generally requires a rather great investment as well as much time for adapting. In addition, the arranging and managing process in Vietnam is still poor, particularly in small and medium companies. This fact results in the decrease of productivity, costs and competency in businesses.

4.1.4. Unable to control the internal resources of materials and still dependent on imported materials

Basically, the resources of materials for timber processing in Vietnam mostly come from two fundamental sites: internal timber resources (natural and planted wood) and 
imported timber resources. The demand for timber materials has recently been increasing due to the need of wood used in the country and the hope for speeding up export activities.

\section{Chart 4.3 Forecast of total demand for timber manufacturing materials and the supplies}

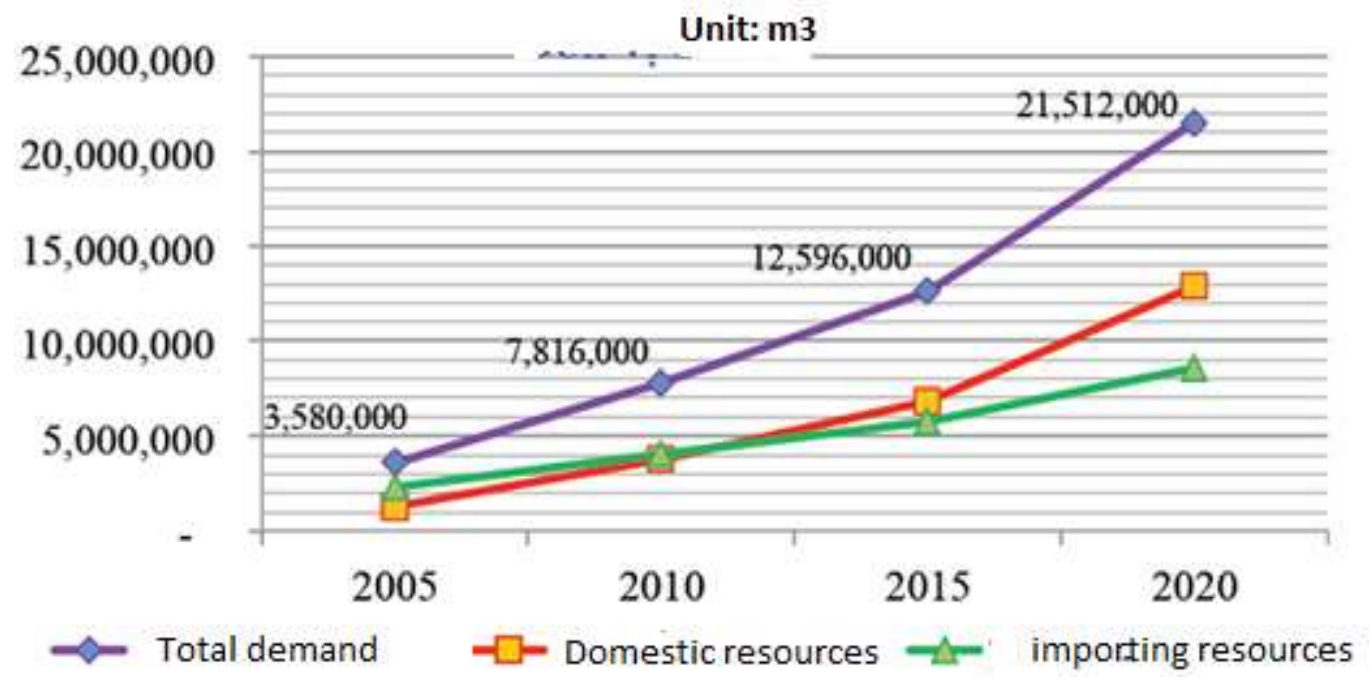

Source: Report on "Helping Associations conduct a research on strategies to develop Wood Industry" of VCCI

Internal timber resources actually cannot meet the demand for timber processing materials due to the short condition of wood areas and substandard exploited timber. According to Mr.Ha Cong Tuan, Deputy Minister of Agriculture and Rural Development Ministry, wood areas in Vietnam have rapidly increased and recently been stable with woods coverage rate growing continuously from 28\% in 1942 to $41 \%$ in early 2014 . However, the quality and biological diversity of natural woods are becoming lower; for evidence, up to $80 \%$ of natural woods areas are in poor conditions. Planted woods are mostly acacias and eucalypti, which are exploited at the age of $6-10$ years, therefore, the sizes of wood are not large enough to meet the requirements for processing materials and it cannot satisfy with the international standard such as ITTO and RED, REACH and Regulation (EU) No 995/2010 and private standards such as FSC, PEFC... 


\section{Chart 4.4: Wood area (thousand hectares) and exploiting quantity (cubic meter) from 2009 to 2013}

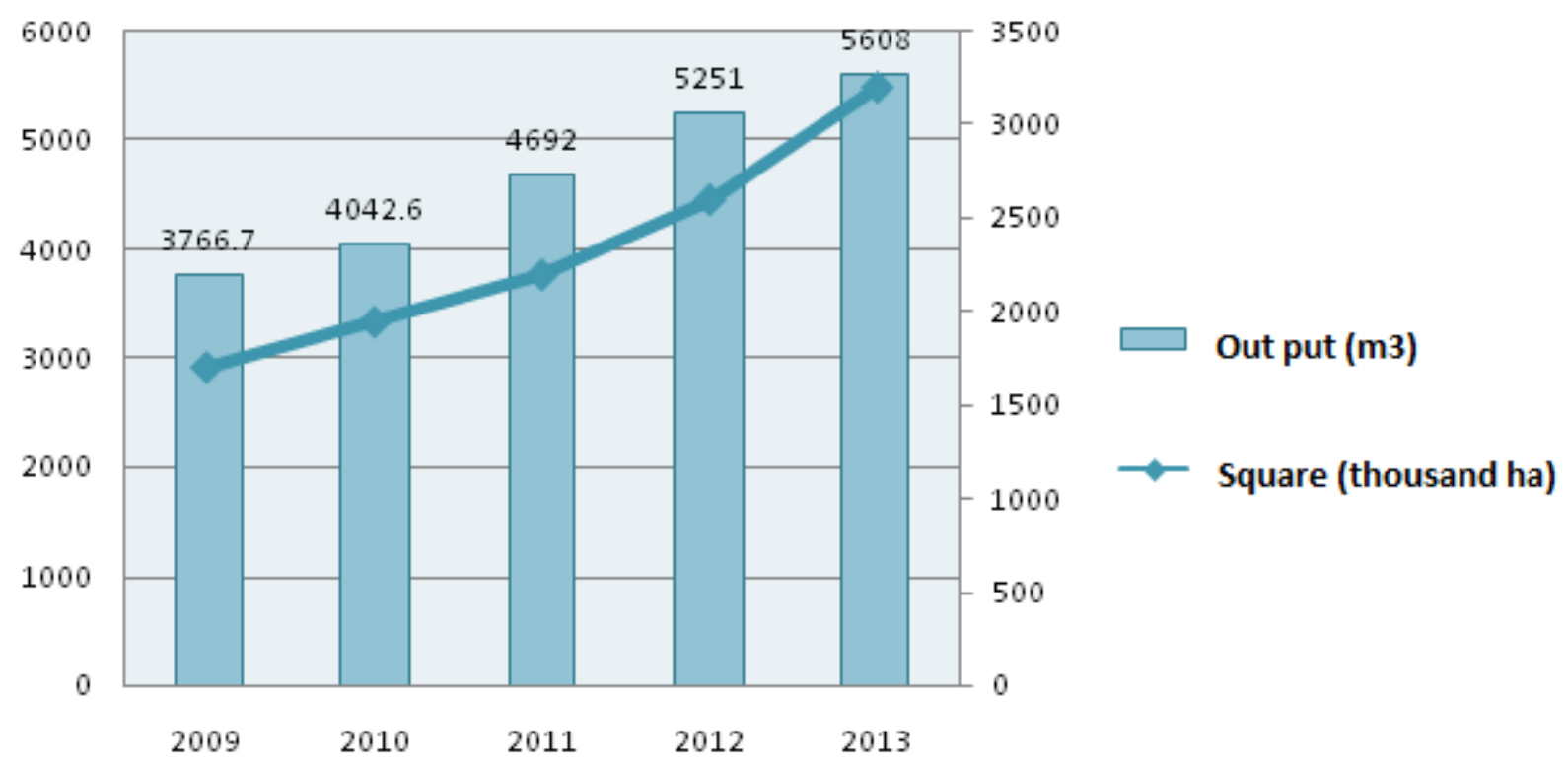

Source: Data from "Report on Economy and Social" of the Government from 2009 to 2013.

Another considerable issue is that the distribution of timber enterprises is not homologous among different planting areas. Many large timber processing enterprises are often located in industrial areas with high-quality facilities and convenient traffic systems connecting to local seaports (concentrated in Southeast areas and Binh Dinh province); however, they are far from the timber planting areas. The number of companies in Northwest area of Vietnam with large woods area only makes up to $1 \%$ of the total number of timber businesses in the country. This is probably an obstacle for some companies such as wood shaving or plank manufacturers which mostly use stable materials because the freight rates will be increased which results in the enterprises' inability to compete.

The quantity of imported timber has been decreased recently; however, it still makes up a large proportion, which leads to the timber industry's inability to supply materials for itself. Before 2000, internal timber materials which took a large proportion of the industry's resources came mainly from natural woods because in the meantime timber export had not actually been developed yet. After that time, the quantity of internally 
exploited wood used in industrial activities started to decrease to only $60-70 \%$ of the total amount. According to statistics of Vietnam Timber and Forest Product Association (VIFOREST), in 2013, the amount of imported timber materials reached 4.5 million cubic meters (made up to $40 \%$ of the total amount). However, in the first 6 months of 2014, this rate decreased to $30 \%$. As to types of wood, imported materials are mostly used for processing timber exports (65-75\% of the total amount) while internal materials only reached at low rate regarding import markets, Vietnam imports timber material from over 100 countries and territories. It is difficult for Vietnam to manage the origin of wood product to export in EU market.

Table 4.1: Timber materials import markets of Vietnam in 2013

(Unit: 1000 USD)

\begin{tabular}{|l|l|l|l|l|l|}
\hline Market & 2013 & $\begin{array}{l}\text { Compared } \\
\text { with 2012 } \\
(\%)\end{array}$ & Market & 2013 & $\begin{array}{l}\text { Compared } \\
\text { with 2012 } \\
(\%)\end{array}$ \\
\hline Laos & 458.886 & 60,86 & Germany & 19.690 & 159,54 \\
\hline USA & 220.035 & 11,84 & Indonesia & 16.970 & 4,85 \\
\hline Malaysia & 91.820 & 2,51 & Finland & 15.807 & 129,63 \\
\hline Thailand & 78.108 & $-9,42$ & Korea & 12.972 & 67,57 \\
\hline Myanmar & 65.964 & 30,69 & Taiwan & 12.489 & 3,07 \\
\hline $\begin{array}{l}\text { New } \\
\text { Zealand }\end{array}$ & 65.084 & 4,18 & France & 10.565 & $-96,64$ \\
\hline Cambodia & 48.580 & 70,09 & Italia & 8.147 & $-9,15$ \\
\hline Chile & 38.113 & 20,15 & Sweden & 7.145 & 3,38 \\
\hline Brazil & 22.792 & $-11,96$ & China & 6.740 & 41,79 \\
\hline
\end{tabular}

Source: Report on "Helping Associations conduct a research on strategies to develop Wood Industry" of VCCI 
As shown in the table above, the main material resource for manufacturing timber exports in Vietnam comes from Southeast Asian countries (including large-size timber, natural solid timber, planted timber and artificial planks). Vietnam also imports a large amount of wood from Oceania countries (planted wood such as acacias and eucalypti); African and South American countries provide planted timber and North American countries supply high-quality wood such as oak and cherries.

\subsubsection{Sales procedures mainly refer to internal markets and indirect export; timber}

\section{manufacturing process is still poor}

Being considered as an export-leading industry, however, according to the Forest Trend, up to 2011, Vietnam's timber industry only contains $20 \%$ of its businesses directly exporting timber. Most of the remaining are indirectly export products and work in internal markets. Those timber directly-export companies are principally large and medium businesses in which FDI companies make up to $57 \%$ of the total number. This group of businesses is divided into two smaller groups: one of them is able to penetrate the EU and American markets; the other mainly works in Asian markets. The larger group of timber companies which export goods indirectly (approximately 80\%) includes outsourcing companies and internal consuming companies. Timber outsourcing is a new developing sales procedure which helps timber companies avoid risks from manufacturing process. However, businesses of this type seem to have poor ability to compete in their markets because of the indirect connection between them and their customers.

In the view of export orientation, timber processing industry in Vietnam exists many problems such as lack of competing ability (outsourcing is still a main procedure of timber processing businesses in Vietnam which makes the companies passive about products and markets); low value added with poor design and lack of creativity which will be difficult to attract customers in EU, USA and Japan, besides nearly 100\% of businesses in Vietnam make payment by FOB which results in low interests and inability 
to access to potential markets and customers, and low productivity (only of 50\% in Philippines, $40 \%$ in China and 20\% in EU - Source: VIFOREST).

\subsection{Timber export in Vietnam}

\subsubsection{Timber export turnover is increasing}

In the past few years, timber manufacturing and processing industry in Vietnam has made surprising progress and reached very high export turnover. According to Mr. Nguyen Manh Dung, Processing Manager of Argo-forestry Aquatic Processing and Salt industry Department (Agriculture and Rural Development Ministry), the turnover of timber export in Vietnam has increased from USD 214 million in 2000 to USD 5.7 billion in 2013 in which it grew $19.2 \%$ more than in 2012, making up to $4.3 \%$ of the total amount of the world. The statistics from the International Trade Center ITC (trade map) in 2013 also shows that Vietnam has reached the position of fourth place in the world timber export ranking with the market share of $4.7 \%$ following China (34.6\%), Italia $(9.3 \%)$ and Germany $(9 \%)$.

Chart 4.5: Timber exports turnover in Vietnam from 2006 to 2014

(Unit: Million USD)

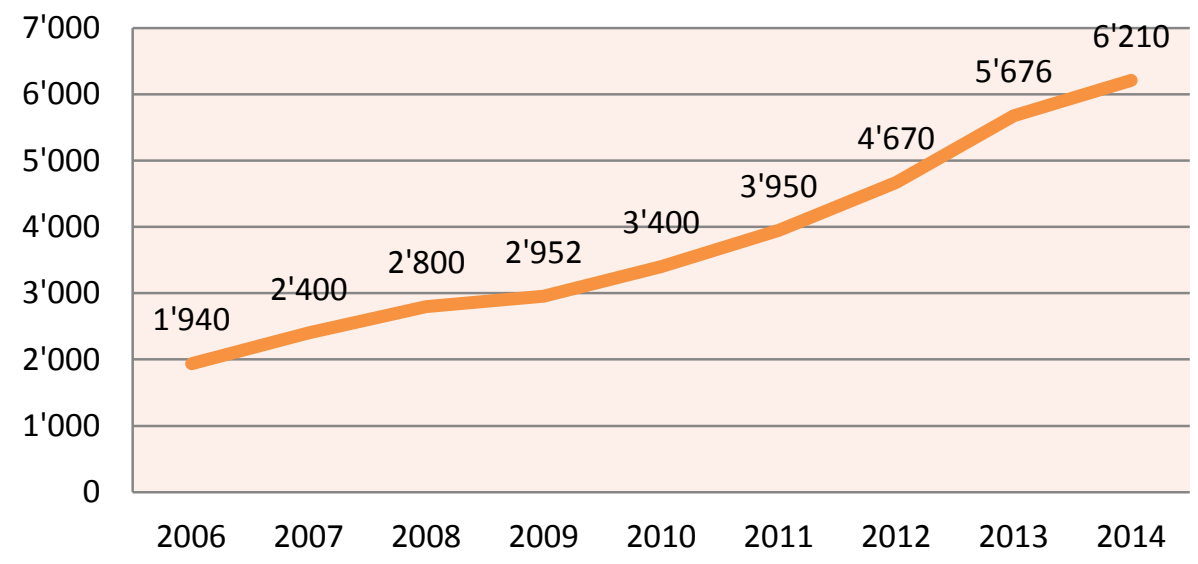

Source: "Annual report on Timber industry of Vietnam in 2014 and Expectations in 2015"

Today, Vietnam's timber export includes a wide range of products. Depending on the specific features of certain goal markets, timber enterprises work out their relevant 
selections of product. Some potential products which make up a large proportion of the total amount of timber exports are: wood shavings, outdoor joineries and furniture. According to VIFOREST, in 2014 Vietnam exported timber and timber products to 106 countries and territories; out of the total amount of export turnover, $60-70 \%$ of them are timber products (code HS 94) such as outdoor joineries, furniture,... and timber (code HS 44) such as wood shavings, spitted timber and so on make up to $36 \%$.

\subsubsection{The timber export market focuses mainly in big markets}

In recent years, timber export enterprises in Vietnam have put a lot of effort into finding and penetrating potential markets with high demand for timber and timber products. However, the main markets of timber is still the USA, EU and some PacificAsian countries.

Chart 4.6: Export market of timber and timber products of Vietnam in 2013

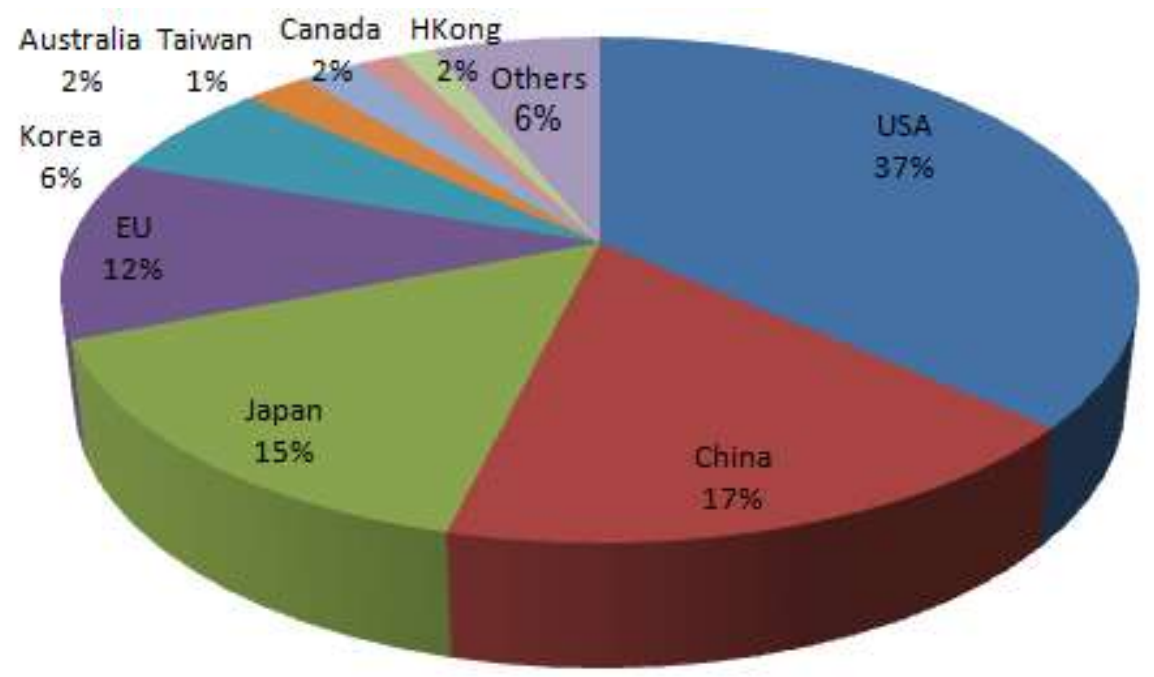

Resource: Data from "Timber industry in 2013 Report" from Trade promotion Website of Ministry of Agriculture and Rural Development

According to the chart, the USA is the largest timber export market of Vietnam (37\% of the total turnover), followed by China, Japan and EU. In the first 8 months of 2014, timber and timber products exported to most of the markets have increased, except in Chinese market in which they decreased $1.69 \%$. Meanwhile, timber exports to the USA 
and Japan have increased relatively by $14.41 \%$ and $23.71 \%$ compared to that in the same period in 2013, the three largest markets account for $62.33 \%$ of the total export value of these items.

Despite many obstacles when penetrating large but highly strict markets with rigid inspection requirements such as the USA and EU, timber products from Vietnam are still rather popular as they meet the consumer tastes with elegant designs, usefulness and reasonable prices.

\subsection{Timber export and import activities between Vietnam and EU}

From 2009 to 2013, although there was a minor decrease in the total export turnover but the EU was still the fourth largest market following the USA, Japan and China. In average, during those 5 years, the EU market accounts for 10-20\% of the total Vietnamese timber products turnover (Ministry of Agriculture and Rural Development, 2015).

\section{Chart 4.7: The turnover of timber export to the EU v. the total turnover of timber export of Vietnam from 2009 to 2014}

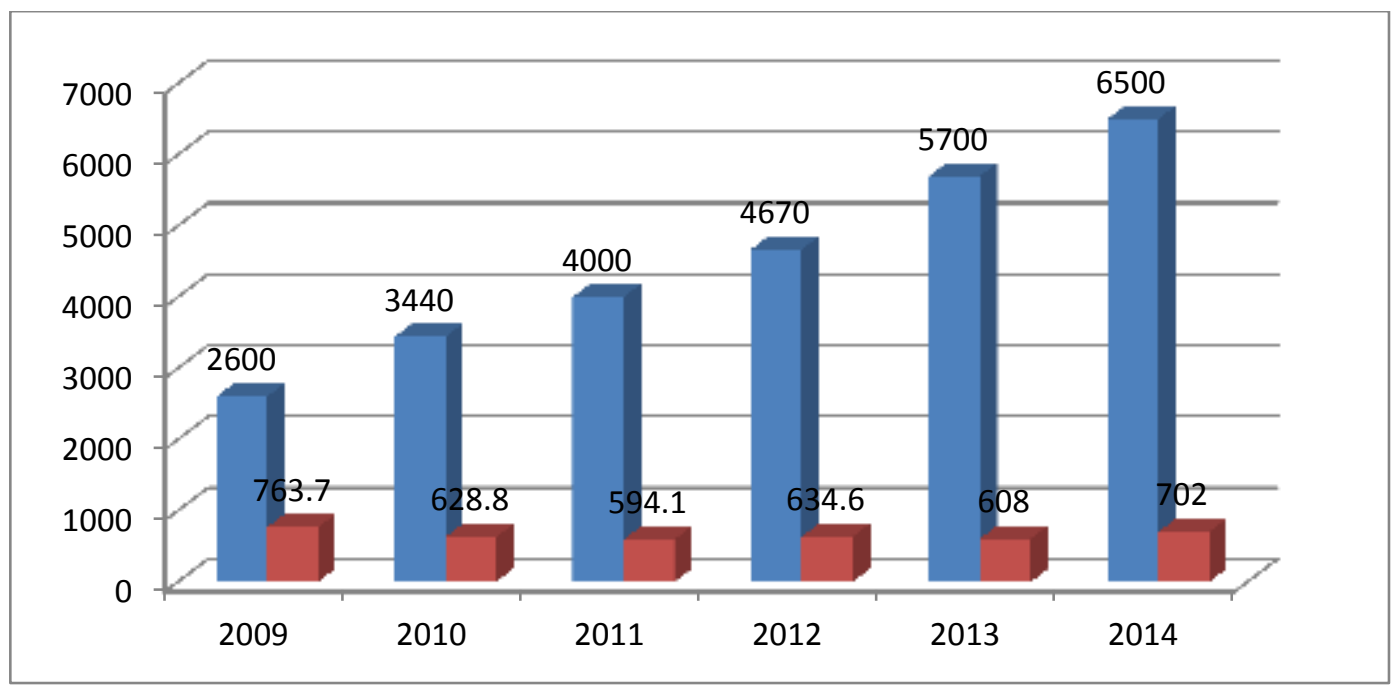

Source: Data from Report on "Helping Associations conduct a research on strategies to develop Wood Industry" of VCCI

Timber products imported into the EU from Vietnam are mainly for interior code HS9403, some for exterior code HS9405 and a small proportion for timber materials 
(code HS44). On the other hand, Vietnam mainly imports from the EU high-quality timber materials for producing luxurious furniture.

Table 4.2. Turnover of furniture export from Vietnam compared with total turnover of furniture import in EU

\begin{tabular}{|l|l|l|l|}
\hline Year & $\begin{array}{l}\text { Turnover of furniture export } \\
\text { in the EU from Vietnam } \\
\text { (thousand USD) }\end{array}$ & $\begin{array}{l}\text { Total turnover of furniture } \\
\text { import in the EU (thousand } \\
\text { USD) }\end{array}$ & $\begin{array}{l}\text { Rate } \\
(\%)\end{array}$ \\
\hline 2006 & 470,988 & $24,752,400$ & $1.9 \%$ \\
\hline 2007 & 632,011 & $30,575,500$ & $2.067 \%$ \\
\hline 2008 & 714,788 & $32,853,400$ & $2.176 \%$ \\
\hline 2009 & 552,194 & $26,021,900$ & $2.122 \%$ \\
\hline 2010 & 605,513 & $26,700,100$ & $2.268 \%$ \\
\hline 2011 & 620,174 & $28,313,200$ & $2.190 \%$ \\
\hline 2012 & 603,972 & $25,663,500$ & $2.353 \%$ \\
\hline 2013 & 579,935 & $25,055,800$ & $2.315 \%$ \\
\hline
\end{tabular}

Source: Data from Report on "Helping Associations conduct a research on strategies to develop Wood Industry" of VCCI

After decreasing by $14 \%$ in 2013 , the timber products import turnover of the EU gradually recovered and increased by $10 \%$ in 2014 (the total imports turnover reached 5.12 million Euro. Imports from China decreased by $16 \%$ in 2013 and increased by $14 \%$ in 2014, reached the turnover of 2.81 million Euro. China is still the largest timber exporter in the EU market (accounts for $54.8 \%$ of the total turnover). In 2014, EU's timber exports turnover from Vietnam started to recover and dramatically increased 19\% (import turnover reached 596 thousand Euro) after the decrease of 9\% in 2013. Vietnam is currently the second largest timber interior exporter, following China, in the EU. 
Chart 4.8: EU 28 import of wood furniture from other suppliers by country - years 2004-2014 (except China)

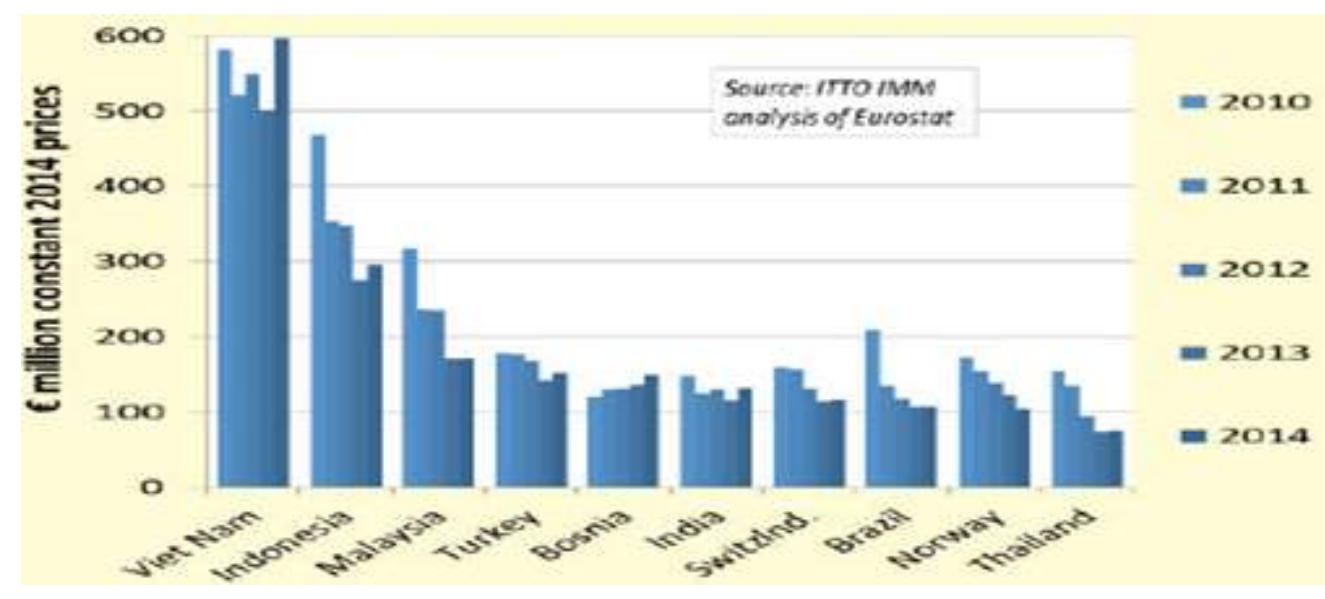

Source: "Report from Europe" of Global Wood in February $2^{\text {nd }} 2015$

Besides timber interior products, Vietnam's timber industry is step by step verifying the export market in the EU by different timber materials, especially the Glulam products. Glulam stands for Glued Laminated Timber Structure in the list. The tropical Glulam product from Vietnam has obtained certain position as being the $3^{\text {rd }}$ highest in the total import turnover of these items in the EU.

\section{Chart 4.9: Tropical Glulam import amount in the EU by market from 2012 to 2014}

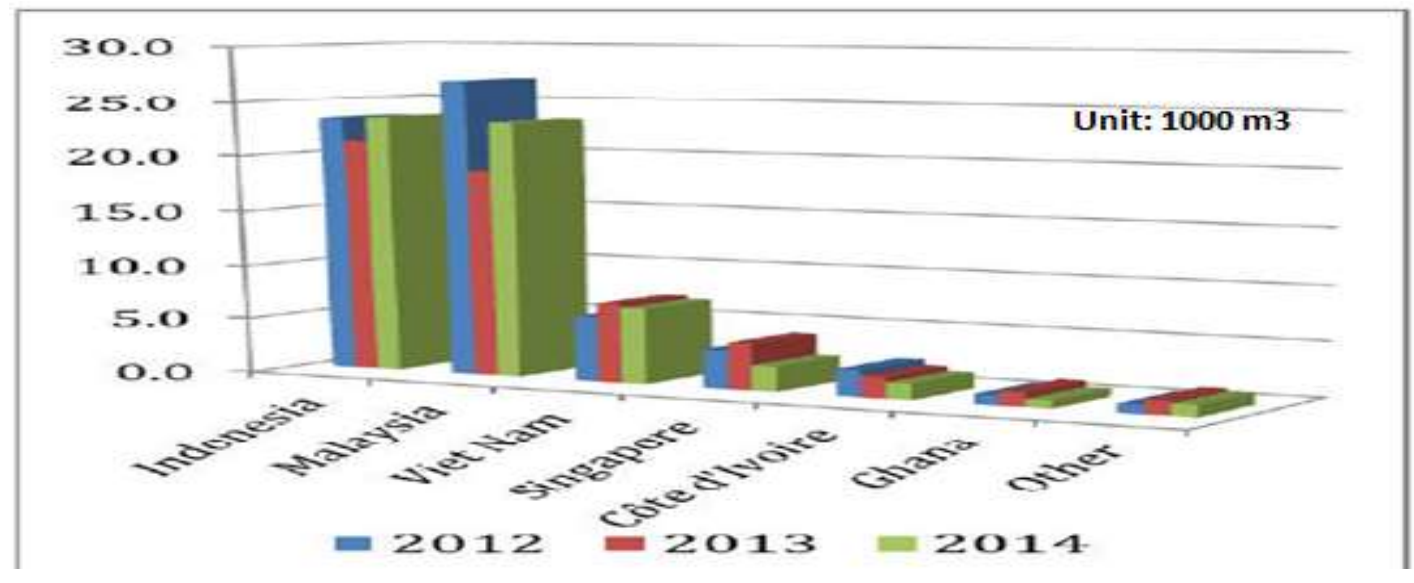

Source: "Report from Europe" of Global Wood in February 2 $2^{\text {nd }} 2015$;

Europe is the largest consumer market of natural and laminated timber flooring. However, laminated timber flooring is more popular than the natural one for its lower 
price. According to the European Federation of the Parquet Industry (FEP), in 2009, natural timber flooring consumption accounted for $14 \%$ of the total flooring consumption, while the laminated one accounted for only 5.6\%. Unlike the timber furniture industry which is affected by Taiwanese and Chinese investors (controlling approximately over a half of the production), Vietnam is rather competitive in the natural timber flooring field thanks to the fact that the natural timber needed for producing is mainly self-supplied from plantations. Although there are still some difficulties such as the shortage of materials and equipment, with the amendment in recent years, natural timber flooring from Vietnam has gained certain position in the world timber import market, especially with the strict importers from the EU. The timber flooring imported in the EU mainly comes from Southeast-Asian and South American countries. In 2014, Vietnam became the $4^{\text {th }}$ largest timber flooring export country in the EU market.

Chart 4.10: Tropical timber flooring import amount in the EU by market from 2012 to 2014

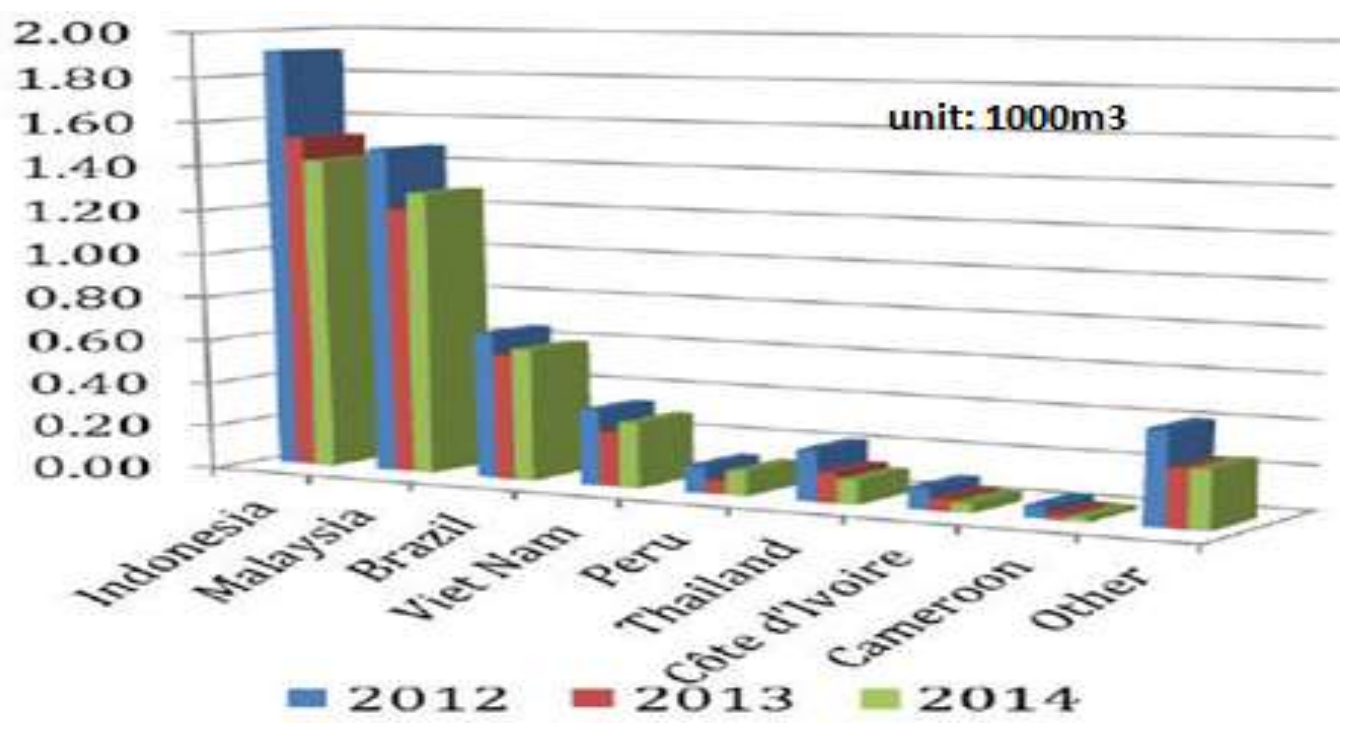

Source: FII Ltd analysis of Eurostat

In brief, during the past few years, although timber and timber products export turnover of Vietnam to the EU market has not have significant improvement, it still shows the potentiality and competitive advantages of Vietnam. Specifically, in 2015 
when Vietnam and EU finished their negotiating on the convention implementation in early 2016, Vietnam's timber industry will have more opportunities to prove its ability among other competitors.

Besides its achievements, the timber industry is facing certain difficulties in legal requirements of the EU with respect to timber. It has been shown that the timber export rate of Vietnam in the EU has slightly decreased in recent years. While the export rate to the EU in 2009 was $29.37 \%$ that in 2013 was only $10.67 \%$. One of the temporary objective reasons was the economic crisis in the Euro zone. Nevertheless, the main reason was that timber products (interior, exterior...) from Vietnam are still restricted by the extremely strict European inspection regulation. From 3 March2015, European timber rules will be taken into consideration in order to deal with the illegal exploitation and trade of timber and timber products. Vietnamese entrepreneurs are allowed to export timber to the EU only if they can guarantee that the statutory origin and sustainability of the timber material comply with the regulation of the FLEGT-VPA. Therefore, complying with the regulation of the FLEGT-VPA is the most important requirement for Vietnamese timber industry in the EU market.

In addition, Vietnamese timber industry is also facing obstacles in increasing the timber export turnover to the EU by diversifying its products. The timber material production in which Vietnam has potential advantages such as woodchips, sawn timber, floorings and laminated timber have not deeply penetrated the EU market as they do not meet the technical specification and origin requirement. Those products are mainly made from domestic timber or illegally imported timber.

\subsection{The requirements to export timber product to the $\mathrm{EU}$ market and the factors affecting exporting activities}

The EU market, one of the biggest wooden furniture consumers in the world, is well known for being highly demanding and it requires constant changes in carpentries' designs (Xuân Lộc, 2014). The competitive advantages of this market are designs and quality rather than price. As a result, besides legal requirements in general, there are 
requirements set out by importers and consumers. This part of the study will analyse requirements for export timber and timber products, and also point out some factors which may affect timber export activities.

\subsubsection{EU legal requirements for timber exporting activities to the $E \boldsymbol{U}$ market}

The most important EU requirements for timber and timber products revolve around legal harvesting. ${ }^{28}$ In 2010 the European Parliament and Council issued the Regulation (EU) No 995/2010 to apply the obligations of operators who place timber and timber products on the market. ${ }^{29}$ The Regulation covers a wide range of timber products listed in its Annex using EU Customs Code nomenclature. ${ }^{30}$ Through this regulation, the EU buyers that place timber or timber products on the market time have to show due diligence and have to trace the products back to the source.

It is also known that the (Illegal) Timber Regulation counters the trade in illegally harvested timber and timber products through three key obligations: the first, it prohibits the placing on the EU market for the first time of illegally harvested timber and products derived from such timber; the second, it requires EU traders who place timber products on the EU market for the first time to exercise 'due diligence'; and the last is require the timber products economic operators in this part of the supply chain have an obligation to keep records of their suppliers and customers.

Once on the market, the timber and timber products may be sold on or transformed before they reach final consumers. To facilitate the traceability of timber products, economic operators in this part of the supply chain (referred to as traders in the regulation) have an obligation to keep records of their suppliers and customers so that if suppliers want to export the timber and timber product into the EU market, they have to provide well-documented guarantees of legality. The EU Timber Regulation (EUTR) is part of the Forest Law Enforcement, Governance and Trade (FLEGT) Action Plan.

\footnotetext{
${ }^{28}$ What requirements should timber products comply with to be allowed on the European market , https://www.cbi.eu/market-information/timber-products/buyer-requirements/, Accessed on 12/11/2015

${ }_{29}$ The Regulation entered into application on 3 March 2013.

${ }^{30}$ ec.europa.eu, http://ec.europa.eu/environment/forests/timber_regulation.htm, Accessed on 12/11/2015
} 
Another part of the plan is the Voluntary Partnership Agreements (VPAs). The FLEGT VPAs are bilateral agreements between the EU and timber exporting countries which aim to guarantee that the wood exported to the EU has a legal source and to support partner countries in improving their own regulation and governance of the sector (Dylan Geraets and Bregt Natens, 2013). The EU has concluded six VPAs with timber exporting countries, and six other VPAs are currently under negotiation. ${ }^{31}$ However, the implementation of the EUTR is still in its infant stage. In many EU member states, the monitoring of trade in illegal timber is still insufficient. At the supply side, at present there are6 growing countries in the final stage of implementing a VPA and 9 other countries are still in the negotiation stage. None of the countries has finalized the VPA-process yet. Compliance is especially common in the North and West EU countries where there is a strong commitment towards legality and sustainability. However, in these regions, (smaller) purchasers can also be less pro-active and not yet fully compliant. What has happened since the implementation of the EUTR is that the supply chain of timber has become more transparent. Exporters also have to pay attention to CITES (international convention on trade in endangered species). With a CITES permit, exporters automatically comply with the requirements of the EU Timber Regulation (EUTR) and their timbers are considered to be legally harvested.

Chemicals in timber: Outdoor timber products are usually applied with preservative such as arsenic, creosotes and mercury to protect them from termites and to enhance their durability. However, EU prohibits timber that has those substance except for some products used for assembling industry and railway sleepers. It also prohibits timber containing certain oils, glue vanishes and lacquers, which can cause toxicity. EU has introduced Regulation (EC) No 1907/2006 of the European Parliament and of the Council of 18 December 2006 concerning the Registration, Evaluation, Authorization and Restriction of Chemicals (REACH).It provides an improved and streamlined legislative

\footnotetext{
${ }^{31}$ Cameroon, the Central African Republic, Ghana, Indonesia, Liberia and the Republic of Congo (Brazzaville) have signed VPAs. The Democratic Republic of Congo, Gabon, Guyana, Honduras, Malaysia and Vietnam are currently negotiating (add Reference)
} 
framework for chemicals in the EU, with the aim of improving protection of human health and the environment and enhancing competitiveness of the chemical industry in Europe. $^{32}$

Certifications: Sustainable forest management, Certification by the Forest Stewardship Council (FSC), the Programmer for the Endorsement of Forest Certification (PEFC) are two main certifications. PEFC's Chain of Custody certification is a mechanism for tracking certified material from the forest to the final product to ensure that the wood, wood fibre or non-wood forest produce contained in the product or product line can be traced back to certified forests. ${ }^{33}$ At the moment FSC is the most widely used scheme for certification of tropical timber forests. The market share of timber and timber products from sustainable sources is high in the market for nontropical timber, especially in North and West EU markets. Besides, Fair Trade is now being tested in timber industry. The Fair Trade concept allows community and small forest owners to be compensated for managing their forests in a sustainable manner through an assurance of fair and premium prices. ${ }^{34} \mathrm{FSC} /$ Fairtrade timber is sold with a Fairtrade premium that adds $10 \%$ added value to wood bought from the certified smallholder communities. It has to be seen whether there is a market for this.

Corporate responsibility: EU buyers wanted to ensure sustainable supply of timber, demonstrate corporate responsibility and minimize reputational risk to their businesses. (EUFLEGT,2013, pg. 2). Important issues are respecting indigenous rights, owner's rights, environmental performance; respecting labour laws and health and safe working conditions. They can ask them to abide to a code of conduct or sign suppliers' declarations to ensure compliance with applicable local laws and regulations, industry minimum standards, International Labour Organization (ILO) and UN Conventions.

\footnotetext{
${ }^{32}$ http://ec.europa.eu/environment/gpp/eu_related_en.htm, Accessed on 12/12/2015

${ }^{33} \mathrm{http} / / /$ pefc.org/standards/chain-of-custody, Chain of Custody

${ }^{34}$ Fair Trade and Timber, http://www.justforests.org/current-campaigns/fair-trade-and-timber , Accessed on $03 / 02 / 2016$
} 
Eco-label for timber $=$ : Eco-labels do not only focus on sustainable sourcing but also on other aspects of the products: processing (e.g. energy consumption, waste management), packaging and use phase (use of preservatives). There are several ecolabels but the most widely recognized label is the EU Eco-label which is available for floor coverings; wood covering and wooden furniture. The number of certified products has grown in recent years but the market is still small. The European Eco-label scheme enables European consumers, including public and private purchasers, to easily identify officially approved green products across the European Union, Norway, Liechtenstein and Iceland. ${ }^{35}$ Introduced in 1992, the label communicates to customers that the marked products meet specific eco-friendly criteria that have been developed to apply to everyday consumer goods and services.

Quality standards: Timber products used for construction have to satisfy requirements relating to: Durability; Environment protection; Health and hygiene; Safety; Noise absorption; Energy saving; Heat preservation. ${ }^{36}$

\section{Technical barriers}

Regulations on labeling: EU has adopted legislations to ensure pest control in wood packaging. The marking used for regulated materials is based on the International Plant Protection Convention compliance symbol shown below:

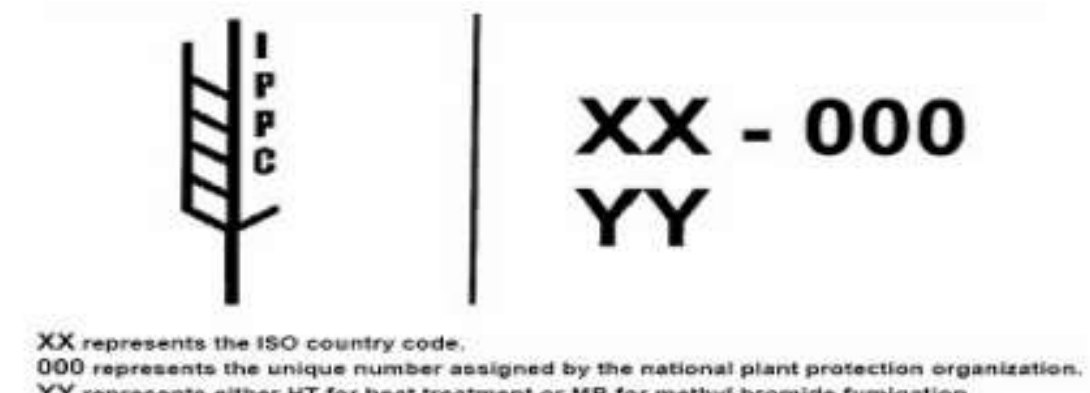

YY represents either HT fer heat treatment or MB for methyl bromide fumigation.

\footnotetext{
${ }^{35}$ The legal base for Eco-label is Regulation (EC) No 66/2010 of the European Parliament and of the Council of 25 November 2009 on the EU Ecolabel.

${ }^{36}$ Some example of non-tariff barrier is listed in annex 2
} 
Found in all "New Approach" legislation with a few exceptions, the CE marking demonstrates that a product meets all essential requirements (typically related to safety, health, energy efficiency and/or environmental concerns).

Regulations on packaging: There is also non-product specific legislation on packaging and liability that apply to all goods marketed in the EU. However, the phytosanitary measures still apply in wood product, as shown in the Revision of ISPM No. 15 - Regulation of wood packaging material in international trade. ${ }^{37}$ From 1 March 2005, the landing requirements apply for wood, wood products and wooden packaging material arriving in the European Community from all countries, except Switzerland. The landing requirement does not apply to wood, wood products and wooden packaging material which is simply moving from one EU member State to another. Additionally there is no phytosanitary certificate requirement for wooden packaging material arriving in the EC, which is ISPM15 compliant as the certification is provided via the ISPM15 wood mark.

Wood packaging material (WPM) will also be affected following EU implementation of ISPM 15 on 1 March. From that date, all WPM, such as boxes, crates, pallets, which are made using any unmanufactured wood products, must meet the new requirements and be either heat treated or fumigated with Methyl bromide under an officially approved programmer and carry the internationally agreed mark. WPM comprises entirely of manufactured wood products such as plywood, particle board, oriented strand board or similar is EXEMPT, and need not to be treated or marked. For WPM manufactured before that date, and until 31 December 2007, the mark only needs to contain the country code, the producer code and the treatment code. After 1 January 2008, all WPM will need to have the full ISPM 15 mark, including the IPPC logo.

Dunnage: From 1 March 2005, and until 31 December 2007, all dunnage must either be bark-free, free of pests and signs of live pests OR be heat treated or fumigated with Methyl bromide and carry the ISPM 15 mark incorporating the country code, the

\footnotetext{
${ }^{37}$ www.ispm15.com/ISPM15_Revised_2009.pdf, ISPM 15 Revised 2009. Accessed on 15/11/2015
} 
producer code and the treatment code. For treated and marked dunnage, there is no requirement for the wood to be debarked until 1 March 2006. After 1 January 2008, all dunnage will need to have the full ISPM 15 mark, including the IPPC logo." 38

Emergency measures: In the meantime the emergency measures covering WPM from Canada, China, Japan and the USA will remain in place, pending review. This means coniferous WPM from these countries must be heat treated, chemically pressure impregnated or Methyl bromide fumigated and marked (and from China, only, be accompanied by a phytosanitary certificate). In addition, non-coniferous WPM from China must be either bark-free and free of insect bore holes $>3 \mathrm{~mm}$ across OR kilndried.

Import documentary: Imported goods must be accompanied by a customs declaration, which has to be submitted in writing, and an invoice in duplicate. The commercial invoice must show the country of purchase and the country of origin of the goods. In addition, a certificate of origin may be required in some cases. Import duties and taxes are subject to change and companies are well advised to verify the correct tariff level shortly before carrying out any export transaction. ${ }^{39}$

\subsubsection{Others requirements from $E U$ importers}

Importers in the EU tend to buy products themselves so exporters need to do research on EU purchasers in order to meet their demands (Xuân Lộc, 2014). Besides the above requirements, there are factors that have influence on the exporting activities of timber exporters and depend on internal situations of enterprises such as: ${ }^{40}$

Reliable: Buyers place reliability above all other considerations. Reliability of supply is crucial to buyers, especially in EU. Reliability is defined as being dependable when it

\footnotetext{
${ }^{38}$ www.timcon.org, http://www.timcon.org/ISPM15/ISPM15GlobalGuide.asp\#EU

${ }^{39}$ Trade Regulations. Customs and Standards http://export.gov/Germany/MarketResearchonGermany/CountryCommercialGuide/TradeRegulationsandStandards/i ndex.asp, Accessed on 12/11/2015

${ }^{40}$ Top 10 tips for doing business with European timber buyers, https://www.cbi.eu/market-information/timberproducts/doing-business/ accessed on 02/04/2016
} 
comes to delivery times; being able to guarantee a steady quality in the product; being good communicators; and in general being honest and good to do business with. If an exporter can convince buyers that it is a reliable supplier, it will be able to do business in Europe. Exporters should be able to show that they have a good track record for reliability; references should be available; and their company image should be professional. If they are not able to prove reliability, they should come up with other ways such as inviting buyers to their factory for few days.

Image of the enterprises: Buyers like the image boost from a fair-dealing supplier. The quality of a supplier's Human Resource Management (HR) and Corporate Social Responsibility (CSR) policy is important to buyers. Buyers need all the positive image builders they can get to keep the balance in the favour. If a supplier has effective HR and CSR policies, a buyer can use these to promote his company to customers in the EU. Buyers often use their suppliers' good image to improve their own market position. "Good" means having effective HR and CSR policies, using sustainable and legal timber, etc. To create a good image in the market, the company website, brochures, house-style, email, footnotes, etc. should all be professional.

Sustainable forestry supply: Buyers will not go against the trend to sustainability. Exporters who have certification in place and can demonstrate continuing progress on this issue will not find it difficult to enter markets. In the future, companies which are unable to keep up with the market's demand for sustainability will have no choice but to leave the European and other advanced markets.

Capacity: To buyers, capacity is another word for quality. Buyers are well aware of the fact that a potential suppliers' capacity in machinery, manpower, raw material and skills is a critical factor in the supplier's ability to supply goods as promised. Buyers would expect their suppliers being able to have enough of each element of this essential foundation in place before the suppliers start promotions or negotiations related to their products. Therefore, export companies should only approach buyers who match their companies' capacity and assure importers that they have a steady timber supply. 
Complying with the law: Buyers will not accept suppliers who ignore Market Access Requirements (MARs) which are important to buyers. When being asked what the most MARs are, buyers tend to put Forest Law Enforcement, Governance and Trade (FLEGT) and CITES at the top of their list. An exporter complying with the FLEGT can attract attention from many European buyers. If an exporter is not certified, it will not have access to the EU market after March $1^{\text {st }}, 2013 .{ }^{, 41}$

\footnotetext{
${ }^{41}$ www.cbi.eu, https://www.cbi.eu/market-information/timber-products/understanding-european-buyers/, How do
} European buyers of timber and timber products think?, access on Febuary $5^{\text {th }}, 2016$. Accessed on 12/12/2015 


\section{Chapter 5 Research methodology}

Besides the application of The Partial Equilibrium Modelling Framework - the WITS/SMART Model of World Bank (Sam Laird and Alexsander Yeats, 1986) to test the change of turnover of Vietnam's Timber industry if all the tariff lines will be cut down to zero, the hypotheses of the study also have been analysed using regression model. The reason for combining these research methods is that each model has its pros and cons, the analysis of regression models based on the factors affecting timber import and export activities of Vietnamese timber enterprises have been mentioned in Chapter 4 will help us take a more comprehensive view of the effects of the EVFTA Agreement to Vietnam Timber industry.

\subsection{WITS/SMART model}

SMART model is developed by the Word Bank to stimulate the partial equilibrium impact of a tariff reduction for a single market. It allows analysis of trade reforms in the presence of imperfect substitutes and is more adequate than homogenous good model when examining tariff preferences, as it avoids corner solutions. In addition, it allows increasing export supply functions: part of the adjustment occurs through changes on the export price of exporters. However, like any partial equilibrium model, these strong assumptions only allow trade policy analysis to be undertaken in one country at a time. In spite of this weakness, WITS/SMART can help estimate trade creation, diversion, welfare and revenue effects.

Smart model based on the assumption (Olivier Jammes and Marcelo Olarreaga, 2005): ${ }^{42}$ 1) Partial Equilibrium: no income effects; 2) Armington Assumption: HS 6 digit goods imported from different countries are imperfect substitutes, i.e., woods from Vietnam are an imperfect substitute to woods from Malaysia. 3) Export supplies are perfectly elastic: world prices of each variety (e.g., wood from Thailand) are given.

\footnotetext{
${ }^{42}$ The techinal description of the model is explained in the annxex
} 
WITS database comes from various sources. It is in close collaboration with the UNCTAD, ITC, United Nations Statistical Division (UNSD) and WTO.

The use of the SMART model is as follows:

- Searching, compile and download the data by country or product based on classification on type of goods and different levels

- Access to information about measuring non-tariff barriers

- Perform commercial and tax queries from reports and partners from countries or groups of countries, products or groups of products specified according to specific standard (HS and SITC) or nomenclative products(BEC, ISIC, GTAP, NACE, ...)

- Calculate and compare trade competitiveness of countries

- Create the simulative assumptions about the single market or multiple markets after tariff cuts

As Vietnamese wood products have an elasticity of supply by price and are under competitive pressure compared to other markets so the SMART model should be simulated with two scenarios:

- Simulation sceneria 1: The Vietnam-EU FTA is concluded successfully with the tax cut to $0 \%$ for all commodity groups mentioned above, supply elasticity is 99 , replaced elasticity is 1.5 (default of the SMART model)

- Simulation sceneria 2: Both the FTA between Vietnam and the EU and FTAs between the EU and other competitive timber markets such as Indonesia, China; Malaysia; Thailand and Brazil are signed (All countries enjoy the preferential tariff of $0 \%$ )

\subsection{Regression model}

\subsubsection{Research design}

The research was divided into two main phases: preliminary research and formal research. These two study periods are presented in detail as follows: 


\subsubsection{Preliminary research}

Preliminary research was carried out through two methods - qualitative research and quantitative research. The purpose of qualitative research is to discover the factors that affect Export-Import turnover Vietnam's Timber Industry with the EU and to adjust the scale to suit the characteristics of Vietnam Timber Enterprises. Qualitative research is conducted by discussing with experts in trade and legal expert to learn the barriers and the obstacles which Vietnam Timber Enterprises have to face at the moment, from which to build a draft scale. The next step, 05enterprises are interviewed in a convenient way of sampling to detect errors of the questionnaires and check-up the scale. The result of this step is to develop a questionnaire used for formal research.

\subsubsection{Formal research}

The formal research was done by means of quantitative research, taken as soon as the questionnaire had been modified from the results of the preliminary research. This study directly interviewed Vietnamese Timber Enterprises to collect survey data. The subjects of this research are Vietnam Timber Enterprises which conducted import and export activities with the EU. SPSS 22.0 software is the main tool for analysing data, testing research framework and testing hypotheses in this research.

\subsubsection{The research hypotheses and the model research}

Based on the factors affecting import and export activities of goods, the issues mentioned in the EVFTA and the requirements of the EU market for timber products, to assess the some factors affecting Vietnam's timber industry as the EVFTA is signed and implemented, the research has developed evaluation models as follows:

Export-Import activities Vietnam's Timber Industry VN-EU $=\beta_{0}+\beta_{1} \mathrm{x} 1+\beta_{2} \mathrm{x}$ $\mathrm{F} 2+\beta_{3} \mathrm{x} 3+\beta_{4} \mathrm{xF} 4+\beta_{5} \mathrm{x}$ F5 $+\beta_{6} \mathrm{x}$ F6

With hypothesizes as following:

H1: Quality standards have negative effect on Export-Import activities Vietnam's Timber Industry with EU. 
$\mathrm{H} 2$ : Technical barriers have negative effect on Export-Import activities of Vietnam's Timber Industry with EU

H3: Administration procedures have negative effect on Export-Import activities of Vietnam's Timber Industry with EU

H4: Environment requirements have negative effect on Export-Import activities of Vietnam's Timber Industry with EU

H5: Corporation responsibility requirements have negative effect on Export-Import activities of Vietnam's Timber Industry with EU

H6: Internal Problems have negative effect on Export-Import activities of Vietnam's Timber Industry with EU

Export-Import activities of Vietnam's Timber Industry VN-EU $=\beta_{0}+\beta_{1} \mathrm{x} 1+\beta_{2} \mathrm{x}$ $\mathrm{F} 2+\beta_{3} \mathrm{x}$ F $3+\beta_{4} \mathrm{xF} 4+\beta_{5} \mathrm{x} 55+\beta_{6} \mathrm{x}$ F6

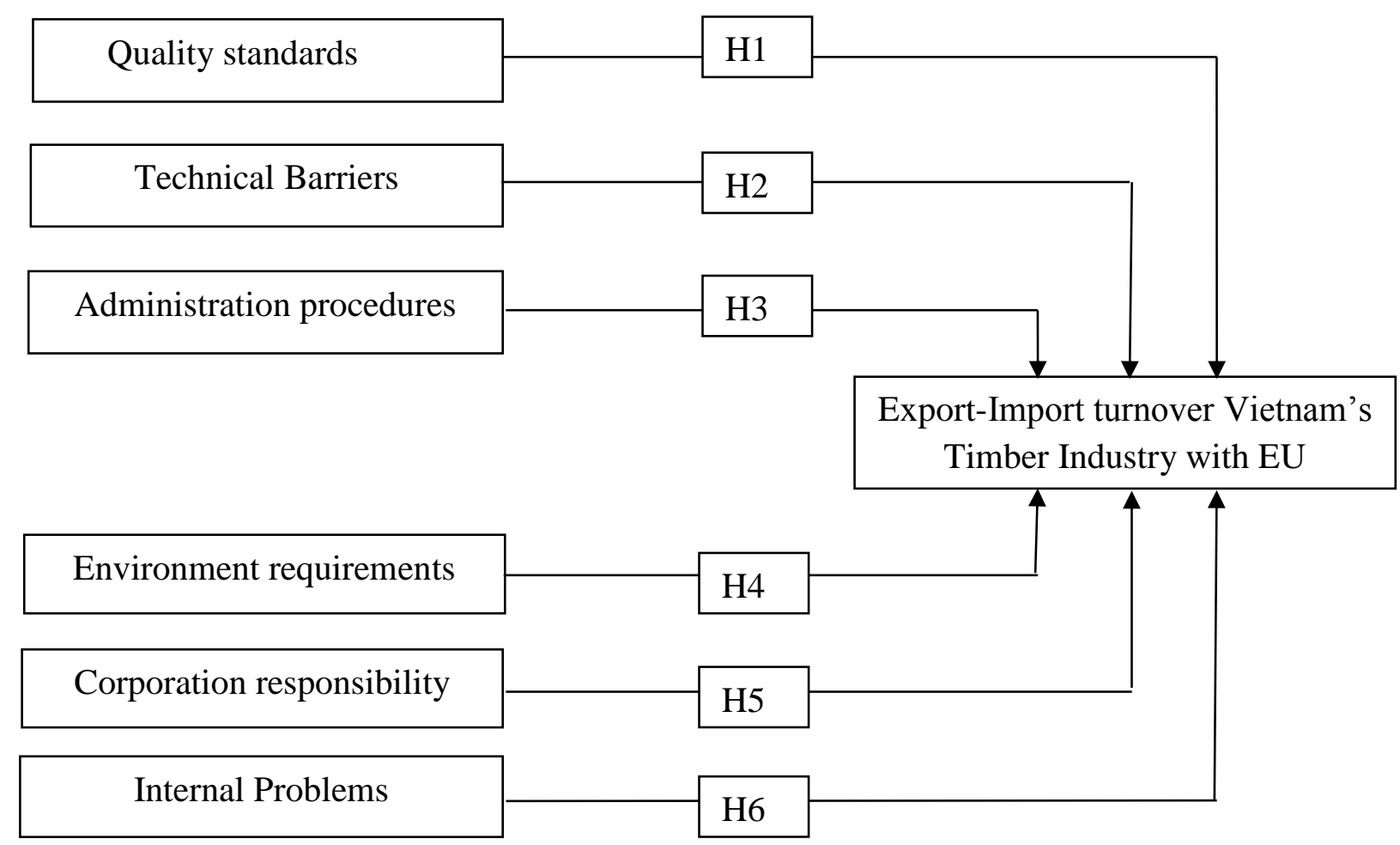

Table 5.1 Model research 


\section{Chapter 6 Research results and analysis}

\subsection{WITS/SMART Results}

Using SMART models with Scenarios are assumed, we have the following results:

- Simulation sceneria 1: The EVFTA is concluded successfully with the tax cut to $0 \%$ for all commodity groups mentioned above, the supply elasticity is 99 , replaced elasticity is 1.5 (default of the SMART model). Table 6.1 shows that at the tax rate of $0 \%$, product code HS 44 rises by 134,843 USD, an increase of approximately $0.155 \%$; product code HS94 increases by 172,528 USD, a respective growth of $0.0159 \%$; these two products will increase by $0.0269 \%$ in total. Thus, although the tax rate applied under the EVFTA is $0 \%$, the export of Vietnamese timber industry to the EU market will increase by about $0.0269 \%$, as the majority of our wood products are currently enjoying the tax rate of $0 \%$.

Table 6.1.SMART simulation results in Scenario 1: The impact of the FTA on Vietnam's wood exports into EU market

\begin{tabular}{|c|c|c|c|c|c|c|}
\hline Code HS & $\begin{array}{c}\text { Trade } \\
\text { value ( } \\
\text { thousand } \\
\text { USD) }\end{array}$ & $\begin{array}{c}\text { Tax } \\
\text { rate is } \\
\text { being } \\
\text { applied } \\
(\%)\end{array}$ & $\begin{array}{l}\text { Tax rate } \\
\text { under } \\
\text { FTA }(\%)\end{array}$ & $\begin{array}{l}\text { Import demand } \\
\text { Elasticity }\end{array}$ & $\begin{array}{l}\text { The } \\
\text { influence } \\
\text { of price }\end{array}$ & $\begin{array}{c}\text { Trade } \\
\text { growth } \\
\text { (thousand } \\
\text { USD) }\end{array}$ \\
\hline 44 & 87400.79 & & & & & 134.843 \\
\hline 441011 & 5.422 & 3.5 & 0 & 1.110107 & 0 & 0.48 \\
\hline 441090 & 2.006 & 3.5 & 0 & 0.557968 & 0 & 0.139 \\
\hline 441112 & 12.584 & 3.5 & 0 & 1.488003 & 0 & 1.269 \\
\hline 441114 & 21.487 & 3.5 & 0 & 1.488003 & 0 & 2.178 \\
\hline 441231 & 712.756 & 5.5 & 0 & 0.881423 & 0 & 87.649 \\
\hline 441232 & 56.74 & 3.5 & 0 & 1.351164 & 0 & 5.412 \\
\hline 441239 & 561.79 & 3.5 & 0 & 0.478907 & 0 & 37.403 \\
\hline 441299 & 1.329 & 5.7 & 0 & 2.854866 & 0 & 0.313 \\
\hline 94 & 1086145 & & & & & 172.528 \\
\hline 940510 & 3270.312 & 0.218 & 0 & 1.080285 & 0 & 18.299 \\
\hline
\end{tabular}




\begin{tabular}{|r|r|r|r|r|r|r|}
\hline 940520 & 3519.648 & 0.4 & 0 & 0.9671149 & 0 & 34.304 \\
\hline 940540 & 7074.125 & 0.6667 & 0 & 1.003903 & 0 & 116.477 \\
\hline 940560 & 367.413 & 0.24 & 0 & 0.5325665 & 0 & 1.776 \\
\hline 940591 & 19.706 & 1.1 & 0 & 0.8598542 & 0 & 0.502 \\
\hline 940592 & 100.138 & 0.6 & 0 & 0.4644265 & 0 & 1.169 \\
\hline Total & \multicolumn{7}{|c|}{ Initial commercial value: 1173546 (thousand dollars) } & $\begin{array}{l}\text { Added value: } \\
\text { 307.371(Thousand } \\
\text { dollars) }\end{array}$ \\
\end{tabular}

Source: Results of the SMART model run by the author

According to the result shown in Table 6.2, when the tax rate on timber is $0 \%$, the EU's timber export to Vietnamese market goes up by $21,446,420$ USD, corresponding to an increase of $10.345 \%$.

Table 6.2.SMART simulation results in Scenario 1: The impact of the FTA on EU's wood exports into Vietnam market

\begin{tabular}{|c|c|c|c|c|c|}
\hline $\begin{array}{l}\text { Reporter } \\
\text { Name }\end{array}$ & $\begin{array}{l}\text { Partner } \\
\text { Name }\end{array}$ & $\begin{array}{l}\text { Product } \\
\text { Code }\end{array}$ & $\begin{array}{l}\text { Exports Before } \\
\text { in } 1000 \text { USD }\end{array}$ & $\begin{array}{l}\text { Exports } \\
\text { After in } 1000 \\
\text { USD }\end{array}$ & $\begin{array}{l}\text { Export Change In } \\
\text { Revenue in } 1000 \\
\text { USD }\end{array}$ \\
\hline Vietnam & Austria & 44 & 1154.848 & 1182.521 & 27.673 \\
\hline Vietnam & Belgium & 44 & 3858.393 & 3883.943 & 25.55 \\
\hline Vietnam & Bulgaria & 44 & 166.497 & 166.497 & 0 \\
\hline Vietnam & Croatia & 44 & 11481.66 & 11481.38 & -0.275 \\
\hline Vietnam & Czech & 44 & 1564.361 & 1564.669 & 0.308 \\
\hline Vietnam & Denmark & 44 & 10218.07 & 10225.69 & 7.619 \\
\hline Vietnam & Estonia & 44 & 2087.258 & 2087.457 & 0.199 \\
\hline Vietnam & Finland & 44 & 16106.26 & 16110.85 & 4.586 \\
\hline Vietnam & France & 44 & 29303.57 & 29331.75 & 28.187 \\
\hline Vietnam & Germany & 44 & 34448.01 & 34865.48 & 417.473 \\
\hline Vietnam & Greece & 44 & 327.094 & 327.094 & 0 \\
\hline Vietnam & Hungary & 44 & 95.89 & 95.89 & 0 \\
\hline Vietnam & Italy & 44 & 5315.862 & 5401.74 & 85.877 \\
\hline Vietnam & Holland & 44 & 604.154 & 685.305 & 81.151 \\
\hline Vietnam & Poland & 44 & 1367.978 & 1639.186 & 271.209 \\
\hline Vietnam & Portugal & 44 & 124.394 & 140.781 & 16.387 \\
\hline Vietnam & Romania & 44 & 1831.867 & 1831.951 & 0.084 \\
\hline
\end{tabular}




\begin{tabular}{|c|c|c|c|c|c|}
\hline Vietnam & Slovak & 44 & 3899.572 & 3900.611 & 1.039 \\
\hline Vietnam & Slovenia & 44 & 186.885 & 189.498 & 2.613 \\
\hline Vietnam & Spain & 44 & 2417.067 & 2421.081 & 4.014 \\
\hline Vietnam & Sweden & 44 & 13131.16 & 13166.01 & 34.843 \\
\hline Vietnam & UK & 44 & 1013.473 & 1029.247 & 15.774 \\
\hline Vietnam & Austria & 94 & 1158.111 & 1466.436 & 308.325 \\
\hline Vietnam & Belgium & 94 & 667.209 & 856.609 & 189.4 \\
\hline Vietnam & Bulgaria & 94 & 0.505 & 0.674 & 0.169 \\
\hline Vietnam & Croatia & 94 & 56.813 & 52.522 & -4.291 \\
\hline Vietnam & Czech & 94 & 358.033 & 398.995 & 40.962 \\
\hline Vietnam & Denmark & 94 & 538.168 & 727.294 & 189.126 \\
\hline Vietnam & Estonia & 94 & 32.298 & 40.759 & 8.461 \\
\hline Vietnam & Finland & 94 & 105.575 & 123.78 & 18.205 \\
\hline Vietnam & France & 94 & 3119.6 & 3964.795 & 845.195 \\
\hline Vietnam & Germany & 94 & 14354.35 & 18806.57 & 4452.226 \\
\hline Vietnam & Greece & 94 & 24.969 & 30.616 & 5.647 \\
\hline Vietnam & Hungary & 94 & 26.3 & 33.662 & 7.362 \\
\hline Vietnam & Ireland & 94 & 3.724 & 4.553 & 0.829 \\
\hline Vietnam & Israel & 94 & 6375.005 & 6231.555 & -143.45 \\
\hline Vietnam & Italy & 94 & 30067.85 & 41764.2 & 11696.36 \\
\hline Vietnam & Holland & 94 & 1307.376 & 1715.363 & 407.987 \\
\hline Vietnam & Poland & 94 & 501.984 & 609.56 & 107.576 \\
\hline Vietnam & Portugal & 94 & 231.997 & 289.694 & 57.697 \\
\hline Vietnam & Romania & 94 & 92.657 & 123.627 & 30.97 \\
\hline Vietnam & Slovak & 94 & 11.353 & 15.338 & 3.985 \\
\hline Vietnam & Slovenia & 94 & 28.183 & 34.966 & 6.783 \\
\hline Vietnam & Spain & 94 & 4556.379 & 5912.367 & 1355.988 \\
\hline Vietnam & Sweden & 94 & 95.571 & 116.167 & 20.596 \\
\hline Vietnam & UK & 94 & 2875.779 & 3691.782 & 816.003 \\
\hline Total & EU & & 207294.1 & 228740.5 & 21446.42 \\
\hline
\end{tabular}

Source: Results of the SMART model by the author

- Simulation sceneria 2: Both the FTA between Vietnam and the EU and FTAs between the EU and other competitive timber markets such as Indonesia, Malaysia; China, Thailand and Brazil are signed (all countries enjoy the preferential tariff of $0 \%$ ). The result in table 6.3 showed a surprise when all the competitors of Viet Nam, such as 
Brazil, China, Indonesia, Malaysia ..., which increasing the value export timber product in EU market but only Vietnam goes down, it seem that the competitiveness of Vietnam's timber products is lower than that countries.

Table 6.3. Synthesis simulation results of the SMART model: Forecasting the impact of the FTA on countries' exports to the EU

\begin{tabular}{|c|r|r|r|}
\hline Country & $\begin{array}{l}\text { Initial commercial value } \\
\text { (thousand dollars) }\end{array}$ & $\begin{array}{c}\text { Trade increased } \\
\text { (thousand dollars) }\end{array}$ & Increase (\%) \\
\hline Total of Vietnam & 1173546 & -4172.01 & -0.3 .5 \\
\hline Total of Brazil & 775165.4 & 25759.81 & 3.323 \\
\hline Total of China & 21079701 & 480400.9 & 2.223 \\
\hline Total of Indonesia & 1107145 & 24674.17 & \\
\hline Total of Malaysia & & & \\
\hline Total of Thailand & 892172.5 & 67954.86 & 2.430 \\
\hline
\end{tabular}

Source: Results of the SMART model by the author

\subsection{Regression model}

Respondent profile: Out of 125 companies being investigated, only $47.6 \%$ of them are wood producing companies, $17.6 \%$ of them are wood dealing companies and the rest $34.4 \%$ are wood proceeding companies. Besides, $24 \%$ of the total amount of these companies export goods both directly and indirectly to EU market, the part of 51.2\% export goods indirectly and the rest $24.8 \%$ export goods directly. Despite that fact, whether their export activities are direct or indirect, the FTA is only known to $80 \%$ of timber companies and the $20 \%$ remaining do not pay much attention to this treaty. This can be explained by the fact that these timber companies export goods indirectly by exporting materials or through another company; therefore, they often ignore this treaty which is a certain obstacle to recent Vietnamese timber enterprises. 
Assessing the credibility of the Scale: Scales was assessed through two preliminary stuff which are Cronbach's Alpha and factor analysis EFA discovery. Cronbach's Alpha was used prior to the type of the "rabbit" variable, the variable has a correlation coefficient item - total correlation of less than 0.3 will be eliminated and the standard selected scale when it has reliability alpha greater than 0.6. Then the factor loading which is less than 0.5 in the EFA will continue to be excluded. The method used is extracted coefficients Principal components with Varimax rotation and stops when extracting factor is 1 . The scale eigenvalue is accepted as the total variance equal to or greater than $50 \%$.

Cronbach alpha analysis: All Cronbach's alpha results on table 6.4are greater than 0.6 , it shows the variables measuring components used in the next EFA analysis.

Table 6.4 Cronbach's alpha results

\begin{tabular}{|l|l|}
\hline Items & Cronbach's Alpha \\
\hline Quality standards (QUAS) & 0.876 \\
\hline Technical barriers (TECB) & 0.621 \\
\hline Administration procedures (ADMP) & 0.655 \\
\hline Environment requirements (ENVR) & 0.899 \\
\hline Corporation responsibility (CORR) & 0.884 \\
\hline Internal Problem (INTP) & 0.816 \\
\hline
\end{tabular}

Source: Results from handling survey data with SPSS

Exploratory Factor Analysis: Factor analysis is used only when the KMO coefficient [Kaiser - Meyer - Olkin] is greater than 0.5. The factor loading which is less than 0.5 will be rejected, stops when Initial Eigenvalue is greater than 1 and the scale is accepted as the total variance is equal to or greater than 0.5. (Hoang Trong and Mong Ngoc, 2005).

Bartlett's test considers the correlation between the observed variables in general. Hypothesis Ho: There is no correlation between the observed variables. (sig. > 0.05) 
$\mathrm{H1}$ : There is correlation between the observed variables (sig $\leq 0.05$ )

Methods of Principal Component Analysis extracted factors with Varimax rotation are used for factor analysis of 25 observed variables. The process of data processing and extraction to remove low-level variables, convergence degree of observed variables was assessed with the EFA.

\section{Table 6.5. KMO and Bartlett's Test}

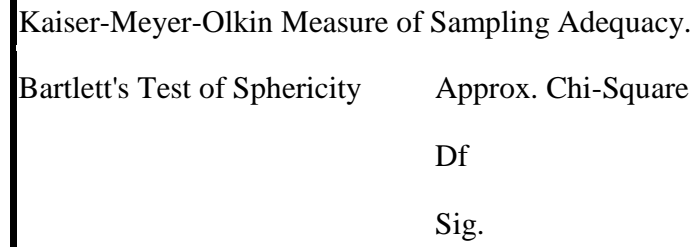

Source: Results from handling survey data with SPSS KMO coefficient $=0.721>0$.and Barlett's Test with sig $=0.000<0.05$ were satisfied.

The final result of analysis is that remaining 20 variables measuring 05 factors as shown in Table 6.5. This result shows that after the type of weights variables is unsatisfactory $(<0.5)$ and stops at the value of 1,016 eigenvalue extracted 5 factors to the variance extracted was $64.228 \%$, satisfactory (> $50 \%$ ). The Technical Barrier (TECB) variables are excluded in EFA, which means that the $\mathrm{H} 2$ also is eliminated from the model $(\mathrm{H} 2$ : Technical barriers have negative effect on Export-Import activities of Vietnam's Timber Industry with the EU)

The component scales observed variables were excluded, the Cronbach's alpha was recalculated, particularly as shown in Table 6.6.

Table 6.6Rotated Component Matrix ${ }^{\mathrm{a}}$

\begin{tabular}{|l|r|r|r|r|c|}
\hline & \multicolumn{5}{|c|}{ Component } \\
\cline { 2 - 6 } & \multicolumn{1}{|c|}{1} & 2 & \multicolumn{1}{|c|}{3} & 4 & 5 \\
\hline V5.2Packaging Regulations & .870 & & & & \\
V5.3Ecolabel & .854 & & & & \\
V5.4 ISO 14001 environmental management Certification & .812 & & & & \\
V5.6Standards of factory & .755 & & & & \\
V5.1 Fumigation/disinfection Certificate & & & &
\end{tabular}




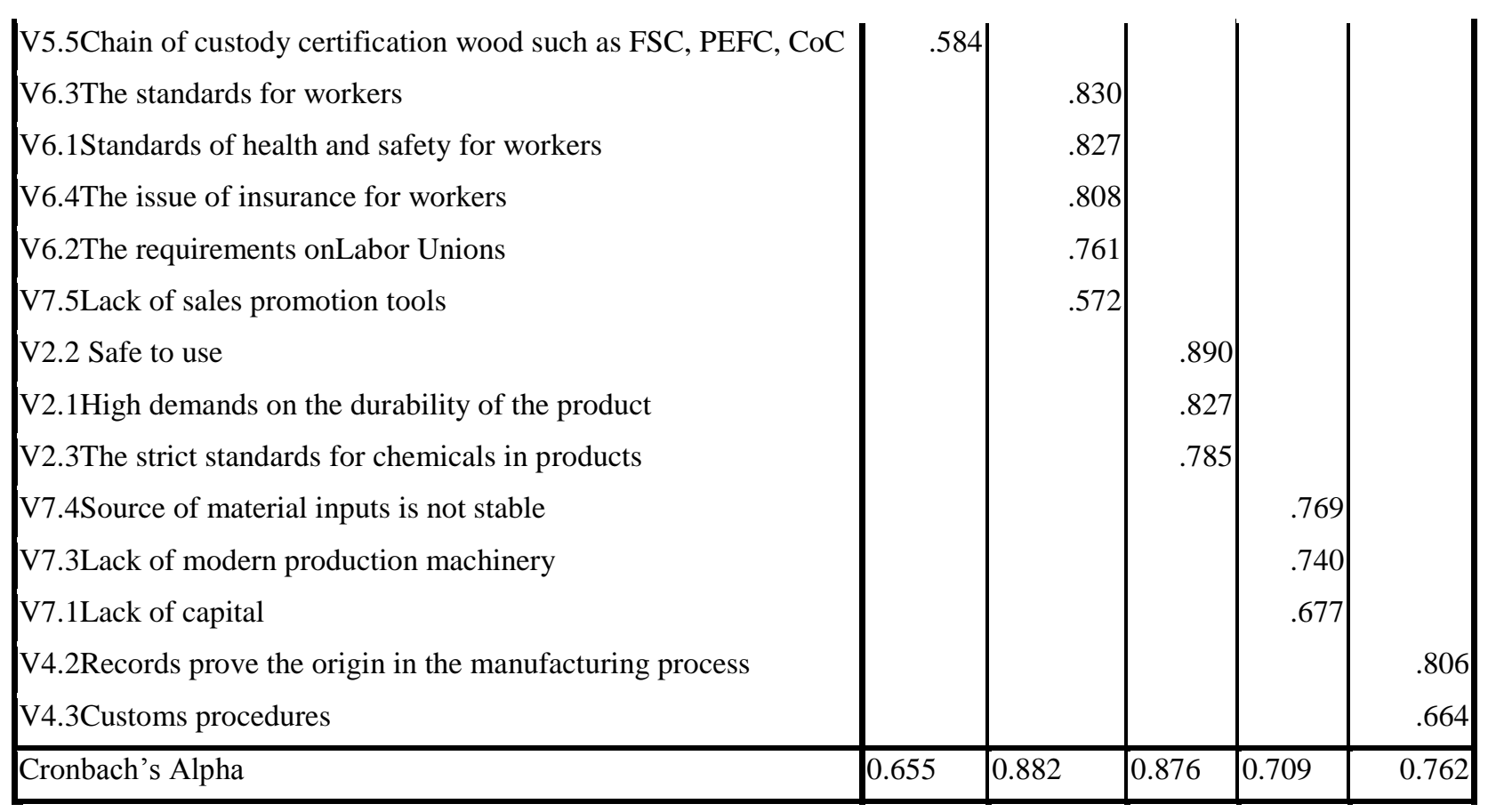

Extraction Method: Principal Component Analysis.

Rotation Method: Varimax with Kaiser Normalization.

a. Rotation converged in 6 iterations.

Source: Results from handling survey data with SPSS

Factors affecting Export exporting activities: Step-wise linear regression model was used to choose variables with great impacts of service quality of VNPT 3G service. Probability of statistics is a standard variable to be used in the model $\mathrm{F} \leq 0.05$ (Probability of F - to - enter). Standard to take a variable from the model is that probability of statistics $\mathrm{F} \geq 0.10$.

Variables used in the model include: Intercept coefficient $\beta_{0}$ and Equivalent regression coefficient: $\beta_{1}, \beta_{2}, \beta_{3}, \beta_{4}, \beta 5$

Independent variables:Environmental barriers (ENVB);Corporate responsibility (CORR); Quality standards (QUAS); Internal problem (INTP); Barriers of administrative procedures (ADMB).

Dependent variable Y: Export-Import activities of Vietnam's Timber Industry with the EU (EXIM) 
The model as follow:

$$
\text { EXIM }=\beta_{0}+\beta_{1} x \text { ENVB }+\beta_{2} \text { CORR }+\beta_{3} x \text { QUAS }+\beta_{4} x \text { INTP }+\beta_{5} x \text { ADMB }
$$

Table 6.7. Coefficients ${ }^{\mathrm{a}}$

\begin{tabular}{|c|c|c|c|c|c|c|c|c|}
\hline \multirow[b]{2}{*}{ Mode } & & \multicolumn{2}{|c|}{ Unstandardized Coefficients } & \multirow{2}{*}{$\begin{array}{c}\text { Standardized Coefficients } \\
\text { Beta }\end{array}$} & \multirow[b]{2}{*}{$\mathrm{T}$} & \multirow[b]{2}{*}{ Sig. } & \multicolumn{2}{|c|}{ Collinearity Statistics } \\
\hline & & $\mathrm{B}$ & Std. Error & & & & Tolerance & VIF \\
\hline 1 & (Constant) & 1.744 & .061 & & 28.587 & .000 & & \\
\hline & ENVB & -.168 & .061 & -.224 & -2.743 & .007 & 1.000 & 1.000 \\
\hline & CORR & .150 & .061 & .200 & 2.445 & .016 & 1.000 & 1.000 \\
\hline & QUAS & .011 & .061 & .014 & .176 & .861 & 1.000 & 1.000 \\
\hline & INTP & -.254 & .061 & -.339 & -4.153 & .000 & 1.000 & 1.000 \\
\hline & ADMB & .032 & .061 & .043 & .526 & .600 & 1.000 & 1.000 \\
\hline
\end{tabular}

a. Dependent

Source: Results from handling survey data with SPSS

Variable: H1.1

Based on the results of the table above, the sig of ADMB and QUAS variables is greater than 0.05 so that it should be exculuated out the model, it means that $\mathrm{H} 1$ and $\mathrm{H} 2$ should be eliminated (H1: Quality standards have negative effect on Export-Import activities of Vietnam's Timber Industry with the EU; H3: Administration procedures have negative effect on Export-Import activities of Vietnam's Timber Industry with the EU)

The model now is: $\mathrm{EXIM}=1.744-0.168 \mathrm{ENVB}+0.15$ CORR- 0.254INTP

The model summary is as shown in Table 6.8, the adjusted R2 Square is 0.398, which means the change of Export-Import activities of Vietnam's Timber Industry with the EU is explained by 3 factors in the model. But this is only true conformity with sample data. To check whether we can infer the overall model for real or not we have to test the suitability of the model.

Testing autocorrelation: With $1.5<$ Durbin-Watson $=1.815<2.5$, so the model has no autocorrelation. 
Table 6.8. R Square

\begin{tabular}{l|r|r|r|r|r}
\hline Model & & & & & Durbin- \\
& $\mathrm{R}$ & R Square & Adjusted R Square & Std. Error of the Estimate & Watson \\
\hline 1 & $.650^{\mathrm{a}}$ & .323 & .398 & .857 & 1.618 \\
\hline
\end{tabular}

b. Dependent Variable: FAC1_2

Source: Results from handling survey data with SPSS

Testing the suitability of the regression model : To test the suitability of the regression model, there are two hypothesis as follows:

Hypothesis Ho: $\mathrm{B}_{1}=\mathrm{B}_{2}=\mathrm{B}_{3}=\mathrm{B}=0$, with the $\mathrm{B}_{\mathrm{x}}$ is the coefficient of regression models.

Hypothesis $\mathrm{H} 1$ : It exists $1 \mathrm{~B}_{\mathrm{x}}$ different 0 , it means $\mathrm{R}_{2}$ different 0 .

Table 6.9. Test the suitability of the regression model ANOVA ${ }^{b}$

\begin{tabular}{|c|c|c|c|c|c|c|}
\hline \multicolumn{7}{|c|}{ ANOVA $^{b}$} \\
\hline & & Sum of Squares & Df & Mean Square & $\mathrm{F}$ & Sig. \\
\hline \multirow[t]{3}{*}{1} & Regression & 64.067 & 5 & \multirow{3}{*}{$\begin{array}{r}12.813 \\
.735\end{array}$} & \multirow[t]{3}{*}{17.426} & \multirow[t]{3}{*}{$.000^{\mathrm{a}}$} \\
\hline & Residual & 87.501 & 119 & & & \\
\hline & Total & 151.568 & 124 & & & \\
\hline
\end{tabular}

a. Predictors: (Constant), REGR factor score 5 for analysis 1, REGR factor score 4 for analysis 1, REGR factor score 3 for analysis 1, REGR factor score 2 for analysis 1, REGR factor score 1 for analysis 1

b. Dependent Variable: EXIM

Source: Results from handling survey data with SPSS

With $\mathrm{F}=17.426$ and Sig $=0.000<0.05$ there should be no correlation between the dependent and independent variables in the model. So with 95\%, it can confirm that the model of multiple linear regression fits our data set and can be generalized to the whole. 


\section{Chapter 7 Implications, Conclusions and Recommendations}

\subsection{Introduction}

The process of analysing primary and secondary information about timber exporting market of Vietnam - EU will play an important role in predicting the result of signing and implementing the EVFTA. This result will provide the government and enterprises with basic grounds for necessary preparation to strengthen the timber market development between Vietnam and the EU.

\subsection{Tariff barrier}

The adoption of SMART/WITS to the theories shows that tariff reduction to level of 0 according to the agreement will bring benefits to the process of timber exporting of Vietnam to the EU and vice versa, so the fact that the two main products code HS44 and HS94 are increasing can be explained. This result can actually be predicted in the view of international trade. However, the increasing level of the EU timber industry's export into Vietnam will be higher than Vietnamese timber export to the EU, which seems to be reasonable as the EU comprises of 27 countries, therefore Vietnamese companies must promote and intensify export activities to the EU market.

However, it is surprising that if the EU reduces the duty rate to $0 \%$ for not only Vietnam but also other competitors who exports timber to the EU market such as China, Malaysia, Thailand, etc....Vietnam's export will become negative, whereas other countries' export will go up. This indicates that if the EU signs FTAs with other countries in the near future, tax and trade remedies ${ }^{43}$ would no longer be effective tools to help Vietnamese timber industry increase its export to the EU. This will require Vietnamese businesses to find solutions in order to enhance attractiveness of their timber products toward the EU market.

\footnotetext{
${ }^{43}$ FTA guarantee market access without trade remedies
} 


\subsection{Non-tariff measures}

The results of regression model show that the impact on Vietnamese timber businesses regarding import and export to EU is Quality standards; Technical barriers and Barriers of administrative procedures have been eliminated from the model, which shows Vietnamese enterprises have been adapted to the requirements set by EU for the above issues. The remaining 3 factors affecting to Vietnamese enterprises' export and import activities are Environmental Barriers, Corporate responsibility and internal problems, in which environmental barriers and Corporate responsibility are factors mentioned in EVFTA.

\section{$\mathrm{EXIM}=1.744-0.168 \mathrm{ENVB}+0.15$ CORR- 0.254INTP}

The regression model reveals that the two variables ENVB (Environmental Barriers) and INTP (Internal problems) have inverse effect to variable COR in respect of import and export activities of Vietnamese companies in the EU market. The more environmental requirements and internal problems of enterprises increase, the more companies' import and export activities decrease, meanwhile, the increasing requirements for social responsibility of enterprises (CORR) will strengthen their import and export activities. This has proved that theories $\mathrm{H} 4$ and $\mathrm{H} 6$ is applicable ( $\mathrm{H} 4$ : Environment requirements have negative effect on Export-Import activities of Vietnam's Timber Industry with the EU; H6: Internal Problems have negative effect on ExportImport activities of Vietnam's Timber Industry with EU) and theory H5 is rejected (Corporation responsibility requirements have negative effect on Export-Import activities of Vietnam's Timber Industry with the EU).

Thus, Vietnamese enterprises are still having difficulties dealing with environmental barriers and internal problems, however, they now begin to adapt to the requirements for social responsibility which can be motivations urging companies to strengthen their import and export activities. Among environmental barriers, it is assessed that the biggest difficulty is the chain of custody certification wood such as FSC, PEFC, CoC (mean = 
3.61, table 7.1), besides, there have been issues regarding of some certifications required by the EU market such as ISO 14001, Fumigation/disinfection Certificate and Packaging Regulations.

Table 7.1 Statistics Mean of Environmental barriers

\begin{tabular}{|l|l|r|r|r|r|r|r|}
\hline & & \multicolumn{1}{|c|}{ V5.1 } & \multicolumn{1}{c|}{ V5.2 } & \multicolumn{1}{c|}{ V5.3 } & V5.4 & V5.5 & \multicolumn{1}{c|}{ V5.6 } \\
\hline \multirow{2}{*}{$\mathrm{N}$} & Valid & 125 & 125 & 125 & 125 & 125 & 125 \\
\cline { 2 - 8 } & Missing & 0 & 0 & 0 & 0 & 0 & 0 \\
\hline \multirow{2}{*}{ Mean } & 3.30 & 3.24 & 3.22 & 3.38 & 3.61 & 3.03 \\
\hline
\end{tabular}

Meanwhile, the biggest barrier of internal problem which the enterprises have to face is instability of the Source of material inputs (Mean $=3.38$, table 7.2). In addition to the inherent difficulties such as capital, high quality human resources and modern machinery also are existing problems of Vietnamese timber enterprises.

Table 7.2. Statistics Mean of Internal Problem

\begin{tabular}{|l|l|r|r|r|r|}
\hline & & V7.1 & V7.2 & V7.3 & \multicolumn{1}{|c|}{ V7.4 } \\
\hline \multirow{2}{*}{ N } & Valid & 125 & 125 & 125 & 125 \\
\cline { 2 - 7 } & Missing & 0 & 0 & 0 & 0 \\
\hline \multirow{2}{*}{ Mean } & & 3.10 & 3.27 & 3.36 & 3.38 \\
\hline
\end{tabular}

Therefore, the assessment based on the content of the EVFTA and the situation of factors affecting Vietnamese timber enterprises mentioned above reveal the opportunities and challenges of the EVFTA to the timber industry of Vietnam as follows:

\subsection{About opportunities}

- Reduce taxes and facilitate the growth of Vietnamese timber exports turnover: although some products are applied with preferential GSP rate of duty, especially some specific interior and exterior furniture of Vietnam which are applied with a rate of $0 \%$, some main timber products exported to EU are still subject to a high rate of duty (from 3.\% to 7\%). Therefore, if the EVFTA is ratified with a rate of in respect of timber products, it will be 
a great opportunities for our major products to hit the market along with a possibility of a growth in timber industry turnover.

- Minimize the technical inspection procedures in respect of timber export to the EU: The EVFTA will become a crucial step for Vietnam and the EU to sign the Voluntary Partnership Agreement (VPA). VPA is a governmental bilateral trade agreement between the EU and Vietnam, in which parties agreed that Vietnam would set up a Timber Legality Assurance System (TLAS) for verifying and licensing the FLEGT for timber shipments and products exported to the EU in order to avoid the responsibility of accountability under EU's timber regulation. Vietnam is able to export timber to the EU without being examined or meet other requirements regarding legality.

- Strengthen the process of science and technology transferring: Apart from purpose of ensuring development and implementation of legal procedures and administration, by implementing the FTA and VPA - FLEGT, the EU also supports Vietnam in setting up facilities and equipment for modern timber producing process in order to obtain the objectives proposed by the agreements.

- Attract investment: One of the most important objectives of FTA is to open up trade and promote investment. Thus, the issues regarding discrimination and international credit will become easier for FDI enterprises to solve, especially for foreign timber companies which account for such small quantities, however produce a large proportion of the market share and exports turnover. Therefore, the promotion of investment as well as the number of FDI timber enterprises will lead to the growth of total Vietnamese timber exports turnover.

- Diversify exports to the EU: Currently, the main timber exports of Vietnam to the EU market are interior and exterior furniture, however, timber material which is one of the primary products of the industry have not penetrated the EU market yet. The pressure on prices of wood chips and plywood of Vietnam in Chinese market which is the main wood chips export market has caused serious loss to Vietnamese timber enterprises. The signing of the EVFTA is a great opportunity for wood chips export industry and other 
wood material products of Vietnam to penetrate into a new challenging but more transparent market.

\subsection{About challenges}

- Increase pressure on non-tariff barriers: Enterprises will have to comply with the legal use of wood throughout the chain of production from planting - exploiting - purchasing and transporting - processing - consumption by the manner of connecting productions among enterprises while Vietnamese companies still actually lack of organizational activities and synchronization. The implementation of changing producing and selling habits of enterprises and wood craft villages is difficult to carry out. In addition, timber enterprises recently are in serious shortage of timber resource certified by Forest Stewardship Council (FSC). In 2014, according to the General Department of Forestry, Vietnam only has approximately 180.000 hectares $^{44}$ of forest certified by FSC which meet the standards on the use of forest resources. Thus, the quantity of standard natural wood is so small that it cannot provide sufficient ground to support the demand of production.

- Increase pressure on prices: Vietnam's timber industry is now depending profusely on imported materials. Currently, Vietnam imports timber materials from 100 countries and territories of which only a few type of them are clearly origin-certified. EVFTA has been signed, under which the legal origins of timber and timber products of Vietnam exported to the member states of EU are required, it would make the price of wood product increasing.

- Increase pressure on redirecting exports: Though the implementation of EVFTA provides Vietnamese timber industry with a great opportunity to export products, the market's taste for furniture are mostly timber designed products with high quality and special models and designs. This requires the change in Vietnamese timber companies' product orientation in order to satisfy the taste of not only EU's member states but also many other developed countries. However, this is not an easy task to conduct due to a

\footnotetext{
${ }^{44}$ On $05 / 2015$, Vietnam has 1,088,700 hectares of forest as the reports of the General Department of Forestry
} 
lack of high-quality workforce which is the most concerning issue of Vietnamese timber processing companies. At the same time, producing high-quality timber products requires an increase in input costs as well as investment in modern equipment. The increase in input costs in accordance with the fact that prices cannot be too high due to competitive pressure in the market leads to Vietnamese timber companies' acceptance to outsourcing which is an interim measure.

- Increase competitive pressure: It is undeniable that the FTA has brought to Vietnamese companies duty-free market access and attracted a lot of investment as well as the development in number of FDI enterprises, and domestic consumers also are beneficial persons when they have more choices with high quality timer product. However, there is also an obstacle to the domestic protection due to the elimination of tariff barriers, antidumping duty and anti-subsidy. In respect of timber industry in particular, there is probably no implementation of principles and rules regarding technical non-tariff barriers or effective implementation. This is one of the most favourable conditions for FDI to hit the timber market that Vietnam accounts for market shares.

Based on the analysis of opportunities and challenges to Vietnamese timber industry, these researches suggest the following points in order to help strengthen timber export and import activities of Vietnamese enterprises to the EU market.

\subsection{Some recommendations}

In respect of government:

- Appropriate policies should be developed to promote the timber export activities, in which:

Restructuring timber exports: Vietnamese companies still remain exporting timber material products code HS 44, especially the sawn and split wood unclear originated from Laos and Cambodia, which continues to place negative impacts on Vietnamese timber products exported to major markets such as EU. This fact requires solutions from the Government which tend to decrease the proportion of primary products and increase the 
proportion of highly processed products with better insurance regarding the legality of input resources for processing.

State should replant industrial regions and material regions along with setting up a system of development policies to promote enterprises and family household participate to plant the standard forests in respect of proactive controlling domestic timber material resources in the future.

Diversifying our products exported to EU: the Government should encourage companies to take advantages of the preferential tariff and competitive advantages derived from signing FTA along with standardizing the production process of these products in order to penetrate into EU market and increase Vietnamese timber exports turnover.

The Government should strengthen administration on origin certificating in respect of imported timber materials as well as enhance forestation certified by FSC in order to meet the quality requirements of materials of EU. Additionally, the Government should conduct propaganda activities to raise the timber enterprises' awareness of responsibility to produce high quality products with a complete legality. Developing programs affiliating timber businesses and forest planters in order to conduct process of legal planting and logging, leading the companies to invest in small households for planting development.

- The Government should develop policies to support enterprises with management; vocational training; credit matters and trade promotion. Vietnamese Timber enterprises are still lack of skill and knowledge in managing the supply chain of products and CSR such as labour, environment problems; so the state should organize the training courses to support them about the problems. In addition to the state need issue technical standards on material wood in order to coordinate with enterprises to manage and control of imported raw materials. State can supply free vocational training or funding high quality skilled the training courses for small and medium enterprises. It is also need to focus on interior design training to meet the demand of EU consumers. State should have preferential credit policies for businesses involved in reforestation activities, processing 
and exporting timber production as well as business in timber supporting industry such as enterprise produce knives, paint sealant and fasteners. To continue sponsoring for timber enterprises participates international trade fair; regularly organize international trade fair in Vietnam, and updated information on the EU market such as culture, legal news, needs of customer.

- Developing some industries which support timber industry such as wood glue, hinge, screw, nail, paint and Surface coating. The result of project "Investigation to situation of timber processing enterprises' export activities to EU's market and the USA's market" conducted by the Centre of Environmental Resources and Rural Poverty reduction Consulting (Vietnam Timber and Forest Products Association) reveals that "up to now we do not have any supporting industry for exported timber processing industry. $90 \%$ of accessories such as knives, paint, glue, hardware and screws are imported from other countries and the $10 \%$ of accessories remaining are made in Vietnam.

\section{In respect of enterprises:}

- Cooperate effectively with the Government and Vietnam Timber and Forest Products Association in order to implement governmental policies timely and effectively.

- Actively explore for timber resources and strictly control their origins.

- Cooperate with other enterprises to create a general strength by participating in timber associations.

- Sustainably develop by updating management production system, training for high quality workforce and applying science and technology.

- Develop a good reputation for Vietnamese timber products by building up the Vietnamese timber brand which emphasis on the sustainability of the product and design. 


\section{Conclusion}

In conclusion, in current economy situation, signing the EVFTA is extremely important to the development and world market integration of Vietnam in general and to our timber industry in particular. Particularly, basing on the study of this Agreement and our manufacture and export situation, the opportunities and challenges in respect of Vietnamese timber industry can be described as follows:

Regarding opportunities, after signing this Agreement, EU will conduct some positive adjustment; especially they will eliminate taxes in order to facilitate Vietnamese timber industry's ability to penetrate EU's market and when the world gradually goes duty-free, with EVFTA as a new type of 'deep integration' agreement, Viet Nam can lead the game in that competition and on the European market. Additionally, EU will become an important partner of Vietnam which provides Vietnamese timber industry with modern scientific and technological facilities due to their strict requirements for the quality of exports. The FTA also create a friendly and favourable legal environment for investors from EU, therefore, it helps increase foreign direct investment as well as the number of FDI timber enterprises supporting Vietnamese timber industry to increase the export turnover and contribute to GDP of Vietnam. The appearance of FDI timber enterprises and opening market EU-VN give customers have more opportunities to access the high quality product from EU.

There are also challenges facing Vietnamese timber industry among which the strict requirements and technical barriers of EU. The implementation of timber producing process in accordance with FLEGT standards requires a total change in the organizational structure of production and management and a change in exports orientation of Vietnamese timber industry, in addition, it still takes much time for enterprises and foresting households to adapt and apply the new rules. Besides, Vietnamese timber industry is now facing the challenge of being competed in the domestic market due to an increase in the number of FDI timber enterprises which have extra effective production and export activities; moreover, they have difficulties competing with other countries in 
EU's timber export market such as the tariff saturated phenomenon after signing FTA or the dependence on imported materials which may lead to increasing prices.

So to be able to take advantage of opportunities and overcome challenges, timber industry is needed the coordinated solutions from governments; industry associations, the timber enterprises and households planting. Specifically, the State needs to change the policy on product structure navigation and orientation for sustainable development and support for exporting businesses; listening to feedback and closely tuned the operation of timber enterprises to be able to make sound recommendations and policy amendments. 


\section{References}

\section{English:}

Cleins C. Coughlin and Geoffrey E. Wood (1989), An Introduction to Non-Tariff Barriers to Trade, Federal Reserve Bank of St Lous

Chan-Hyun Sohn and Hongshik Lee (2005), FTAs and Income Covergenve, International conference on "Economic Intergration and Structrual Changes in East Asia, Yokohama National University.

Claudio Dordi, (2016), Impacts of the EVFTA on the EU's and Vietnam's Enterprises Legal Issues, presentate on the EU-Vietnam Free Trade Agreement - Legal issues Workshop, Hanoi Law University

David Greenaway (2009), Financial factors and exporting decisions, University of Nottingham

Dirk Michael Boehe and Luciano Barin Cruz (2009), How does Corporate Social Responsibility influence Export Performance, EnANPAD, Sao Paulo

Dylan Geraets and Bregt Natens (2013), the WTO constensy of the EU Timber regulation, the Leuven Centre for Global Governance Studies (KU Leuven).

Ganeshan Wignaraja (2010), How Do FTAs Affect Exporting Firms in Thailand? Asian Development Bank Institute

Jose R. Brenes et al. (1992) Effectiveness of Alternative Export Promotion Strategies For Branded Food Products, Journal of Food Distribution Research

Lili Yan Ing, Shujiro Urata, Yoshifumi Fukunaga (2015), How Do Exports and Imports Affect the Use of Free Trade Agreements? Firm-level Survey Evidence from Southeast Asia, The Use of FTAs in ASEAN: Survey-based Analysis, ERIA Research Project Report 2013-5, Jakarta: ERIA, pp.1-24.

Love, Patrick and Ralph Lattimore (2009), Protectionism? Tariffs and Other Barriers to Trade, in International Trade: Free, Fair and Open?, OECD Publishing, pg. 7

Mustapha Sadi Jallab (2007), The Free Trade Agreement Between the United States and Morocco. The Importance of a Gradual and Assymetric Agreement, Journal of Economic Integration, 2007, 22 (4), pp. $852-887$

Mutrap (2011), The free trage agreement between Vietnam and the European Union:

Quantitative and qualitative impact analysis, page 217, Report, Hanoi.

Olivier Jammes and Marcelo Olarreaga (2005), Explaining Smart and GSIM, The Word Bank 
Sam Laird, Alexsander Yeat (1986), The UNCTAD Trade policy simulation model, A note on the methodology, data and uses, United Nation.

Tulin Ural et al. (2006) The Effects of Firm's Strategic Factors on Export and Firm Performance: A Comparison of Permanent and Sporadic Exporters, Problems and Perspectives in Management, Volume 4, Issue 4, 2006

Titus Lee, Tan Kok Kong (2011), Do free trade agreement master? Evaluating the impact of FTAs on Singapore's domestic exports of goods, Economic Survey of Singapore Second Quarter 2011

Tuotuo Yu and Sandra Poncet (2013), Pollution havens, environmental trade barriers and international regulatory spillover: A firm level study of China, Paris School of Economics

Tran Dinh Van (2014), Trade capacity Vietnam Grand opening \& Public-Private dialogue on Impacts of VN-EU FTA on SMEs Conferences in Hanoi

Yot Amornkitvikai et al (2012), Factors affecting the export participation and performance of Thai manufacturing small and medium sized Enterprises (SMEs), University of Wollongong,

Vietnamese

Phòng Thương mại và Công nghiệp Việt Nam (VCCI) (2015), Báo cáo Nghiên cúu "Hỗ trọ Hiệp hội thực hiện nghiên cứu chiến luợc phát triển ngành chế biến gố" Ủy ban tư vấn về Chính sách Thương mại Quốc tế - Trung tâm WTO - Phòng Thương mại và Công nghiệp Việt Nam (2014), Nhũng thách thức tự do thương mại Việt Nam 2015, Bản tin Doanh nghiệp và chính sách Thương mại Quốc tế số 20 - 21

Tô Xuân Phúc, Trần Lê Huy, Nguyễn Tôn Quyền (2014), Báo cáo "Tổng quan cung cầu gố tại Việt Nam: Thưc trạng và xu hướng”

Trần Lê Huy (2014), Báo cáo "Việt nam xuất khẩu dăm gỗ 9 tháng đầu 2014" Trần Lê Huy, Tô Xuân Phúc (2015), Báo cáo: "Ngành công nghiệp dăm gỗ Việt Nam: Thực trạng và xu hướng phát triển trong tuoong lai" Mộng Ngọc và Hoàng Trọng (1999), Phân tích dũ liệu đa biến, Nhà xuất bản thống kê. Hoàng Trọng (2005), Phân tích dữ liệu nghiên cứu với SPSS, Nhà xuất bản thống kê. Tô Xuân Phúc, Trần Lê Huy, Cao Thị Cẩm (2014), Báo cáo “Xuất nhập khẩu gỗ tròn và gố xẻ của Việt Nam năm 2014", 
Hiệp hội Gỗ và Lâm sản Việt Nam (2014),Thực thi hiệp định VPA/FLEGT: Nhận thưc và hành động của cộng đồng doanh nghiệp gỗ Việt Nam, Tạp chí Gỗ Việt số 59 tháng 8 năm 201

Nguyên Thiết (2014), Gỗ Việt: Xuất nhiều, nhập cũng nhiều; Tạp chîThông tin Tài chính số 22 kỳ 2 tháng 11 năm 2014

\section{Websites:}

Dr Franz Jessen (2015), EU-Vietnam: 25 years of deepening partnership and a bright future, 2015.

Website: http://eeas.europa.eu/delegations/vietnam/press_corner/all_news/news/2015/20150129_e n.htm (Accessed on 18 November 2015) Xuan Truong (2015), Competitive challenges when participating in FTA Vietnam - EU, http://kinhdoanh.vnexpress.net/tin-tuc/doanh-nghiep/thach-thuc-canh-tranh-khi-tham-giafta-viet-nam-eu-3106515.html (Accessed on 19 November 2015)

Nguyen Thu Trang (2011), Experience about Free Trade Agreement with the EU, Website: http://trungtamwto.vn/vn-eu-fta/hiep-dinh-thuong-mai-tu-do-voi-eu-kinhnghiem-tu-nhung-nguoi-di-truoc (Accessed on 22 November 2015) Thanh Thanh (2014a), EU and Vietnam reach agreement on free trade deal, http://europa.eu/rapid/press-release_IP-15-5467_en.htm (Accessed on 20 November 2015).

Thanh thanh (2014b), Vietnamese enterprises remain indifferent to the technical barriers to trade, Website: http://baocongthuong.com.vn/doanh-nghiep-viet-van-tho-o-voi-cacrao-can-ky-thuat-trong-thuong-mai.html (Accessed on 22 November 2015) My Chau (2013), Vietnam - EU FTA: Challenges and Opportunities for Vietnam's Timber and Forest Product

Industries,http://vccinews.com/news_detail.asp?news_id=28300 (Accessed on 23 November 2015)

Trung tam WTO (2014), Workshop: Free Trade Agreement Vietnam-EU, notice for Vietnamese enterprises, 2014 http://trungtamwto.vn/vn-eu-fta/hoi-thao-hiep-dinh-thuongmai-tu-do-viet-nam-eu-nhung-noi-dung-doanh-nghiep-viet-nam-can (Accessed on 18 November 2014)

Cao Chi Cong (2015), FLEGT negotiations between Vietnam and the EU: Find common ground to promote wood industry. http://goviet.org.vn/bai-viet/tien-trinh-dam-phan-flegt- 
giua-viet-nam-va-eu-tim-diem-chung-de-nganh-go-vuon-xa-8259, Gỗ Việt (Accessed on 24 November 2015)

Xuan Loc (2014), Tìm đường đưa gỗ Việt vào EU,

http://www.doanhnhansaigon.vn/chuyen-lam-an/tim-duong-dua-go-viet-nam-vao-thitruong-eu/1082119/ Accessed 20/12/2014

Ngoc Nam (2015), Wood processing enterprises are optimistic with the trend of integration?http://vov.vn/kinh-te/doanh-nghiep/doanh-nghiep-che-bien-go-lac-quantruoc-xu-the-hoi-nhap-426515.vov (Accessed on 25 November 2015)

Nguyen Tuong Van (2015), FLEGT-VPA: In order to promote wood industry, http://baocongthuong.com.vn/hiep-dinh-vpaflegt-de-go-viet-nam-vuon-xa.html, Bao Cong Thuong (Accessed on 25 November 2015)

Thanh Huyen (2014), Essential requirements when exporting furniture to the EU, http://www.taichinhdientu.vn/Home/Yeu-cau-song-con-khi-xuat-khau-do-go-sangEU/20147/135983.dfis (Accessed on November 2015)

Ngoc Bich - Chu Chinh (2015), Timber exports to EU: The Impact of FLEGT. http://vtv.vn/viet-nam-va-the-gioi/xuat-khau-go-vao-thi-truong-eu-tac-dong-tu-flegt20150708152644447.htm (Accessed on 25 November 2015)

Business in Brief 12/5, http://english.vietnamnet.vn/fms/business/130360/business-inbrief-12-5.html, Accessed 20.03.2016.

The Trade promotion website - Ministry of Agriculture and Rural Development http://xttm.mard.gov.vn/

link: http://www.globalwood.org/market/timber_prices_2015/aaw20150202e.htm Tìm được đưa gỗ Việt Nam vào Eu;

http://www.bvsc.com.vn/News/2014623/294693/tim-duong-dua-go-viet-nam-vao-thitruong-eu.aspx Accessed on 04/01/2015

https://www.cbi.eu/market-information/timber-products/buyer-requirements/ http://ec.europa.eu/environment/forests/timber_regulation.htm, Timber regulation http://ec.europa.eu/environment/gpp/eu related_en.htm

\section{http://pefc.org/standards/chain-of-custody, Chain of Custody}

Fair Trade and Timber, http://www.justforests.org/current-campaigns/fair-trade-andtimber

International developments in trade in legal timber, http://www.euflegt.efi.int/documents/10180/23025/All+you+need+to+know+about+the+ 
US+Lacey+Act,\%20the+EU+Timber+Regulation+and+the+Australian+Illegal+Logging +Prohibition+Act+2012/b30e8b52-f093-448d-be57-9ae7677259f1, pg 2 www.ispm15.com/ISPM15_Revised_2009.pdf, ISPM 15 Revised 2009. www.timcon.org, http://www.timcon.org/ISPM15/ISPM15GlobalGuide.asp\#EU Trade Regulations. Customs and Standards; http://export.gov/Germany/MarketResearchonGermany/CountryCommercialGuide/Trade RegulationsandStandards/index.asp https://www.cbi.eu/market-information/timber-products/understanding-european-buyers I, How do European buyers of timber and timber products think?, accessed on Febuary $5^{\text {th }}, 2016$.

Viet Delta Corporation(2014), "Tình hình xuất khẩu gỗ, sản phẩm gỗ và dự báo" http://woodvietnam.com.vn/tinh-hinh-xuat-khau-go-san-pham-go-va-du-bao/ Global Wood (2014), Report from Europe http://www.globalwood.org/market/timber_prices_2014/aaw20141002e.htm Global Wood (2015), Report from Europe http://www.globalwood.org/market/timber_prices_2015/aaw20150202e.htm European Commission (2014),TARIC measure information http://ec.europa.eu/taxation_customs/dds2/taric/measures.jsp? Lang=en\&Taric $=44 \& G o o$ $\underline{d s T e x t}=\&$ Domain $=$ TARIC \&MeasText $=\& O f f s e t=125 \&$ Area $=V N \&$ ExpandAll $=\&$ callback uri $=C B U-1 \&$ LangDescr $=\&$ SimDate $=20150318$ 


\section{Annex 1: Technical Description of the UNCTAD Trade Policy Simulation Model}

The basic model can be described in a series of equations and identities from which the formulation for the simulations is derived.

First the notation is given: NOTATION

M - imports $\quad$ Mn - imports from non-preference-receiving countries

$\mathrm{X}-$ exports $\quad \mathrm{V}$ - output in the importing country

$\mathrm{P}$ - price $\quad \mathrm{R}$ - revenue

$\mathrm{W}$ - welfare $\quad \mathrm{t}$ - tariff rate or non-tariff distortion in

Y - national income ad valorem terms

Em - elasticity of import demand with respect to domestic price

Ex - elasticity of export supply with respect to export price

Es - elasticity of substitution with respect to relative prices of the - same product from different sources of supply

TC - trade creation

TD - trade diversion

i - subscript denoting commodity

j - subscript denoting domestic/importing country data

$\mathrm{k}$ - subscript denoting foreign/exporting country data

- (In certain expressions the subscript $\mathrm{K}$ is used to denote data for an - alternative foreign/exporting country)

$\mathrm{d}$ - prefix denoting change

Examples:

Pijk - Price of commodity $i$ in country $j$ from country k (i.e. domestic price in $\mathrm{j}$ )

Pikj - Price of commodity i from country k to country j (i.e. export/world price j)

Mijk - Imports of i by j from k Xikj - Exports of $\mathrm{i}$ by $\mathrm{k}$ to $\mathrm{j}$

The basic model The importing country j's import demand function for commodity i produced in country k may be expressed as: 
(1) $\mathrm{Mijk}=\mathrm{F}(\mathrm{Yj}, \mathrm{Pij}, \mathrm{Pik})$

The producer/exporting country k's export supply function for commodity i may be expressed as:

(2) $\mathrm{X} \mathrm{ijk}=\mathrm{F}(\mathrm{P}$ ikj $)$ Expressions (1) and (2) are related by the following identity:

(3) $\mathrm{M} \mathrm{ijk}=\mathrm{X} \mathrm{ikj} \mathrm{Assuming} \mathrm{that} \mathrm{in} \mathrm{a} \mathrm{free} \mathrm{trade} \mathrm{situation} \mathrm{the} \mathrm{domestic} \mathrm{price} \mathrm{of} \mathrm{the} \mathrm{commodity} \mathrm{i}$ in the importing market $\mathrm{j}$ will be equal to exporting country k's export price plus transport and insurance charges, it follows that this price will rise by an amount equivalent to the ad valorem incidence of any tariff or non-tariff distortion applied to the good. Thus:

(4) $\mathrm{P}$ ijk $=\mathrm{P}$ ikj $(1+\mathrm{t} i \mathrm{jk})$ It is also clear that the export revenues earned by $\mathrm{k}$ are :

(5) $\mathrm{R}$ ikj = X ikj .P ikj Trade creation The trade creation effect is the increased demand in country $\mathrm{j}$ for commodity $\mathrm{i}$ from exporting country $\mathrm{k}$ resulting from the price decrease associated with the assumed full transmission of price changes when tariff or non-tariff distortions are reduced or eliminated. Given the basic model consisting of expressions (1) to (5), it is possible to write the basic formula for trade creations. First, from expression (4) it is possible to derive the total differential of domestic price with respect to tariffs and foreign price:

(6) $\mathrm{dP} i \mathrm{jk}=\mathrm{P} \mathrm{ikj} \cdot \mathrm{dt} \mathrm{ijk}+(1+\mathrm{t} \mathrm{ijk}) \cdot \mathrm{dP}$ ikj Now, the standard expression for the elasticity of import demand with respect to the domestic price can be rearranged as follows: (7) dM ijk /M ijk $=$ Em. $(\mathrm{dP}$ ijk $/ \mathrm{P}$ ijk $)$

Substituting from expression (4) and (6) into expression (7) gives:

(8) $\mathrm{dM}$ ijk $/ \mathrm{M} \mathrm{ijk}=\mathrm{Em} \cdot(\mathrm{dt} \mathrm{ijk} /(1+\mathrm{t} \mathrm{ijk})+\mathrm{dP}$ ijk $/ \mathrm{P} \mathrm{ikj})$

The standard expression for the elasticity of export supply with respect to the world price can be rearranged as follows:

(9) $\mathrm{dP} \mathrm{ikj} / \mathrm{P} \mathrm{ikj}=(\mathrm{dX} \mathrm{ikj} / \mathrm{X} \mathrm{ikj}) / \mathrm{Ex} 22$

From expression (3) it follows that:

(10) $\mathrm{dM} \mathrm{ijk} / \mathrm{M} \mathrm{ijk}=\mathrm{dX}$ ikj $/ \mathrm{X}$ ikj

Substituting expression (10) into (9) and the result into (8) produces the expression that can be employed to compute the trade creation effect. From expression (3) this is equivalent to exporting country k's growth of exports of commodity $i$ to country $j$. The expression for trade creation can be written:

(11) $\mathrm{TC}$ ijk = M ijk . Em.dt ijk /((1+t ijk ).(1.(Em/Ex)) 
It may be noted that if the elasticity of export supply with respect to the world price is infinite then the denominator on the right hand side of expression (11) becomes unity and can be ignored.

\section{Trade diversion}

Following standard practice, the term trade diversion is used to account for the tendency of importers to substitute goods from one source to another in response to a change in the import price of supplies from one source but not from the alternative source. Thus, if prices fall in one overseas country there will be a tendency to purchase more goods from that country and less from countries whose exports are unchanged in price. Trade diversion can also occur not because of the change in the export price as such but because of introduction or elimination of preferential treatment for goods from one (or more sources) while treatment for goods from other sources remains unchanged. Again there could be simply a relative change in the treatment of the goods from different sources in the importing country by differential alterations in the treatment of different foreign suppliers. (i) Without explicit values for the elasticity of substitution If the elasticity of substitution between alternative suppliers is not known then it is still possible to compute the trade diversion effect using a formulation developed by Baldwin and Murray.19 However, for this approach it is necessary to be able to calculate the level of import penetration by non-preference-receiving countries, i.e. the level of imports from non-preferencereceiving countries in apparent domestic consumption (defined as domestic output of commodity i plus imports of commodity i less exports of commodity i). The formulation for trade diversion can then be written:

(13) $\mathrm{TD}$ ijk = TC ijk .(Mn ij/V ij )

This formulation assumes "the substitutability between a developing country product and a similar product produced in non-beneficiary i.e. non-preference-receiving countries should be similar to the substitutability between a developing country product and a similar product produced in the donor importing country" (Id.).

19 Baldwin, R.E. and Murray, T. "MFN tariff reductions and developing country trade benefits under the GSP". The Economic Journal 87, March 1977. 23 (ii) With explicit values for the elasticity of substitution If explicit values are available for the elasticity of substitution between goods from different sources then it is not necessary to use the approach outlined above. Alternatively, if there are no market penetration data available then there may be no option but to assume values for the elasticity of substitution (and conduct simulations across a range of reasonable estimates). It is possible to define the elasticity of substitution as the percentage change in relative shares associated with a one percent change in the relative prices of the same product from alternative sources. 
That is: (14) $\mathrm{Es}_{-}=\frac{\mathrm{d}(\Sigma \mathrm{M} \mathrm{ijk} / \Sigma \mathrm{M} \mathrm{ijK}) /(\Sigma \mathrm{M} \mathrm{ijk} / \Sigma \mathrm{M} \mathrm{ijK})}{\mathrm{d}(\mathrm{P} \mathrm{ijk} / \mathrm{P} \mathrm{ijK}) /(\mathrm{P} \mathrm{ijk} / \mathrm{P} \mathrm{ijK})}$ where $\mathrm{k}$ denotes imports from one (group) of foreign supplier(s), $\mathrm{K}$ denotes imports from another (group) of foreign supplier(s), and the summation is only across the country group $\mathrm{k}$ or $\mathrm{K}$ but not across product groups (i) nor across imports (j). From this expression it is then possible to express the percentage change in the relative shares of the alternative suppliers in terms of the elasticity of substitution, the percentage change in relative prices and the original relative shares of imports from the alternative sources. By extensive expansion, substitution and rearrangement, it is possible to obtain the following expression for the change in imports from one country - or trade diversion (TD) gain or loss, as the case may be - as a result of the change in duty paid prices relative to the prices from other sources resulting from a commercial policy change:

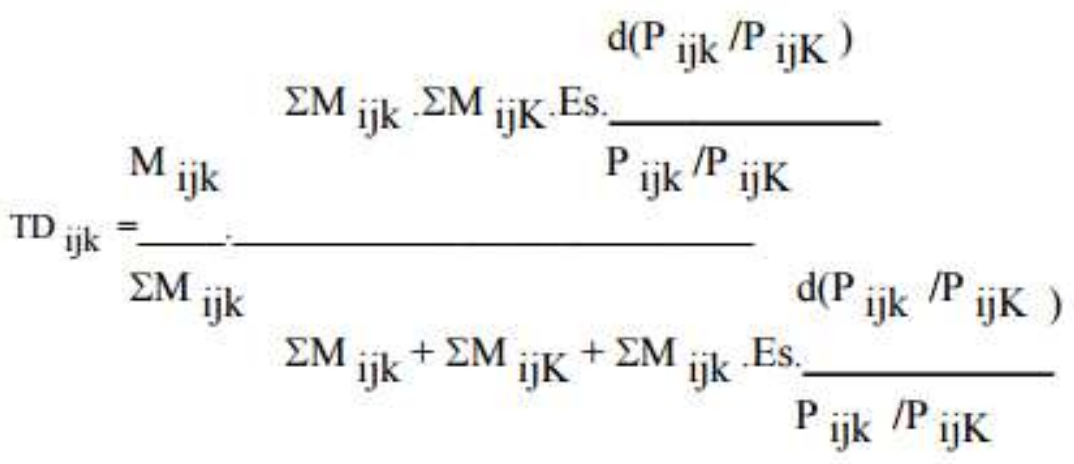

The term in expression (15) for the relative price movement is specified in terms of the movements of the tariffs or the ad valorem incidence of non-tariff distortions for the two foreign sources. Expression (15) is the equivalent of the final expression for trade diversion given by Cline (op. cit.). As in Cline, similar expressions can be derived to obtain separate results for the different groups of foreign/exporting countries. Alternatively, the results can be summed for one group, and this sum can be distributed among members of the alternative group of foreign suppliers in accordance with their prior share in the imports from that group. 24 The total trade effect The total trade effect is obtained simply by summing together the trade creation and trade diversion effects. Results can be summed for the imported across product groups and/or across sources of supply. Results can be summed across groups of importers for single products or groups of products as well as for single sources of supply or for groups of suppliers. Results can also be summed for suppliers across product groups. Finally, results can be summed for groups of suppliers either for individual products or across product groups. The price effect If the export supply elasticity is infinite then there is no price effect on exports. Otherwise the price effect can be obtained by substituting expression (10) into (9), giving:

(16) $\mathrm{dP} \mathrm{ikj} / \mathrm{P} \mathrm{ikj}=(\mathrm{dt} \mathrm{ijk} /(1+\mathrm{t} \mathrm{ijk})) .(E m /(E m-E x))$ 
The revenue effect Expression (16) has direct application in estimating the revenue effect for the exporting country. If the export supply elasticity is infinite, there is no price effect - as noted above - and consequently revenue increases in proportion to the increase in exports. Otherwise the percentage increase in revenue is equal to the percentage increase in exports plus the percentage increase in prices. This can be shown by taking from expression (5) above the total differential of revenue with respect to export price and the volume of exports:

(17) $d R i k j=P i k j . d X i k j+X i k j . d P i k j$

Dividing the left-hand side (LHS) of (17) with the LHS of expression (5) and the right-hand side (RHS) of (17) with the RHS of (5) gives:

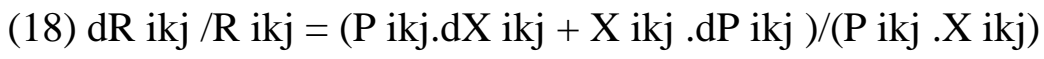

Reducing and substituting from expression (10) gives:

(19) $\mathrm{dR}$ ikj $/ \mathrm{R} \mathrm{ikj}=(\mathrm{dM} \mathrm{ikj} / \mathrm{M} \mathrm{ijk})+(\mathrm{dP} i \mathrm{kj} / \mathrm{P} \mathrm{ikj})$ Alternatively, this can be written:

(20) $\mathrm{dR} \mathrm{ikj} / \mathrm{R} \mathrm{ikj}=(\mathrm{dt}$ ijk $/(1+\mathrm{t}$ ijk $)) . E m .((1+\mathrm{Ex}) /(\mathrm{Ex}-\mathrm{Em}))$

The welfare effect The welfare effect arises from the benefits consumers in the importing country derive from the lower domestic prices after the removal or reduction of tariffs or the ad valorem incidence of non-tariff distortions. As noted by Cline (op.cit.), "for the pre-existing level of imports, any price reduction to the consumer merely represents a transfer away from the government of tariff revenue formerly collected on the import and therefore no net gain to the country as a whole. But for the increase in imports, there is a net welfare gain equal to the domestic consumers' valuation of the extra imports minus the cost of extra imports at supply price (excluding tariffs)". Thus, the net welfare gain is normally estimated as the increase in import value times the average between the ad 25 valorem incidence of the trade barriers before and after their elimination. This welfare gain can also be thought of as the increase in consumer surplus.

It can be written:

(21) $\mathrm{W}$ ijk $=0.5(\mathrm{dt}$ ijk. dM ijk)

In the case where the elasticity of export supply is less than infinity the supply price is higher than previously. The new domestic price of imports does not decline to the full extent of the tariff change and import expansion is less than in the case of infinitely elastic export supply. Welfare can still be computed using expression (21) but needs to be interpreted as a combination of consumer surplus and producer surplus. 
Annex 2: Some examples of Eu non-tariff barriers applied for wood product

(HS 44; 94)

\begin{tabular}{|c|c|c|c|}
\hline ProductCode & \multirow{2}{*}{\multicolumn{2}{|c|}{$\begin{array}{l}\text { MeasureDescription } \\
\text { Plant health control: The imports into the European } \\
\text { Union (EU) of plants, plant products and any other } \\
\text { material capable of harbouring plant pests (e.g. } \\
\text { wooden products and containers, soil, etc) may be } \\
\text { subject to the following protective measures, as esta }\end{array}$}} & StartDate \\
\hline 44011000 & & & $\begin{array}{l}\text { 1/1/2012 } \\
12: 00: 00 \mathrm{AM}\end{array}$ \\
\hline 44219097 & \multicolumn{3}{|c|}{$\begin{array}{l}\text { In relation to wood packaging, the provisions introduced by Commission Directive } \\
\text { 2004/102/EC (OJ L-309 06/10/2004) (CELEX 32004L0102) establish that wood } \\
\text { packages of any type (cases, boxes, crates, drums, pallets, box pallets and other load } \\
\text { boards, pallet }\end{array}$} \\
\hline 44190010 & $\begin{array}{l}\text { Only the substances included in the Union list } \\
\text { of authorised substances set out in Commission } \\
\text { Regulation (EU) No 10/2011 (OJ L-12 } \\
\text { 15/01/2011) (CELEX 32011R0010) may be } \\
\text { used for the manufacture of these products. } \\
\text { Note: The Union List of authorised substanc }\end{array}$ & & $\begin{array}{l}\text { 1/1/2012 } \\
12: 00: 00 \mathrm{AM}\end{array}$ \\
\hline 44012100 & $\begin{array}{l}\text { Special rules for materials and articles intended } \\
\text { to come into contact with foodstuffs All } \\
\text { materials and articles intended to come into } \\
\text { contact with foodstuffs, including packaging } \\
\text { materials and containers, must be manufactured } \\
\text { so that they do not transfe }\end{array}$ & & $\begin{array}{l}\text { 1/1/2012 } \\
\text { 12:00:00 AM }\end{array}$ \\
\hline 44190090 & $\begin{array}{l}\text { The label of these products shall include the text } \\
\text { "for food contact" or shall bear the symbol with } \\
\text { a glass and a fork. Commission Regulation (EC) } \\
\text { No 2023/2006 (OJ L-384 29/12/2006) (CELEX } \\
\text { 32006R2023) lays down the rules on good } \\
\text { manufacturing practice (GM }\end{array}$ & & $\begin{array}{l}\text { 1/1/2012 } \\
12: 00: 00 \text { AM }\end{array}$ \\
\hline 44190010 & $\begin{array}{l}\text { Polyamide and melamine plastic kitchenware } \\
\text { originating in or consigned from China and } \\
\text { Hong Kong shall be imported into the Member } \\
\text { States only if the importer submits to the } \\
\text { competent authority for each consignment a } \\
\text { declaration confirming that it meets th }\end{array}$ & & $\begin{array}{l}\text { 1/1/2012 } \\
\text { 12:00:00 AM }\end{array}$ \\
\hline 44072945 & $\begin{array}{l}\text { The measure affects exclusively illegally } \\
\text { harvested timber and their derived products is } \\
\text { prohibited }\end{array}$ & & $\begin{array}{l}\text { 1/1/2013 } \\
\text { 12:00:00 AM }\end{array}$ \\
\hline 44219097 & $\begin{array}{l}\text { The labelling must indicate the volume in the } \\
\text { case of liquid products and the weight in the } \\
\text { case of other products. The label of the } \\
\text { prepacked product must also bear the weight } \\
\text { and volume indications used in trade practice or } \\
\text { comply with the national regulations }\end{array}$ & & $\begin{array}{l}\text { 1/1/2014 } \\
12: 00: 00 \text { AM }\end{array}$ \\
\hline
\end{tabular}




\begin{tabular}{|c|c|c|}
\hline 44219097 & $\begin{array}{l}\text { The packaging of these kind of goods must bear } \\
\text { specific inscriptions and markings } \\
\text { such as the identification of the packer, the } \\
\text { person responsible for the packing or the } \\
\text { importer established in the EU, and the EEC } \\
\text { mark, a small 'e', that must be placed in }\end{array}$ & $\begin{array}{l}\text { 1/1/2014 } \\
12: 00: 00 \mathrm{AM}\end{array}$ \\
\hline 44061000 & $\begin{array}{l}\text { Essential requirements: The essential } \\
\text { requirements to be met are laid down in Annex } \\
\text { III of the mentioned Directive. Essential } \\
\text { requirements on safety, health, reliability, } \\
\text { environmental protection and technical } \\
\text { compatibility are set up globally for each ra }\end{array}$ & $\begin{array}{l}\text { 1/1/2012 } \\
12: 00: 00 \mathrm{AM}\end{array}$ \\
\hline 94059900 & $\begin{array}{l}\text { Producers are required to register with the } \\
\text { competent authority appointed by the Member } \\
\text { State and have data reporting obligations } \\
\text { relating to the amount and categories of EEE } \\
\text { put on the market and relevant levels of } \\
\text { recycling achieved. The information to }\end{array}$ & $\begin{array}{l}\text { 1/1/2012 } \\
12: 00: 00 \mathrm{AM}\end{array}$ \\
\hline 94021000 & $\begin{array}{l}\text { Registration of representatives and devices. } \\
\text { Manufacturers who place Class I, custom-made } \\
\text { devices or systems and procedure packs on the } \\
\text { market and who do not have a registered place } \\
\text { of business in a Member State, must designate a } \\
\text { a single authorised repre }\end{array}$ & $\begin{array}{l}\text { 1/1/2012 } \\
12: 00: 00 \mathrm{AM}\end{array}$ \\
\hline 94059900 & $\begin{array}{l}\text { EEE as well as electric light bulbs and } \\
\text { luminaires in households shall not contain lead, } \\
\text { mercury, cadmium, hexavalent chromium, } \\
\text { polybrominated biphenyls (PBB) or } \\
\text { polybrominated diphenyl ethers (PBDE) in } \\
\text { amounts exceeding the set of maximum } \\
\text { concentration v }\end{array}$ & $\begin{array}{l}\text { 1/1/2012 } \\
\text { 12:00:00 AM }\end{array}$ \\
\hline 94043000 & $\begin{array}{l}\text { Restriction on the use of certain chemical } \\
\text { substances in textile and leather products The } \\
\text { placing on the EU market of textile and leather } \\
\text { articles containing certain chemical substances, } \\
\text { group of substances or mixtures are prohibited } \\
\text { or severely restricte }\end{array}$ & $\begin{array}{l}\text { 1/1/2013 } \\
12: 00: 00 \mathrm{AM}\end{array}$ \\
\hline 94055000 & $\begin{array}{l}\text { The presentation of the product, the labelling, } \\
\text { any warnings and instructions for its use and } \\
\text { disposal and any other indication or information } \\
\text { regarding the productThe General Product } \\
\text { Safety Directive (GPSD) establishes the } \\
\text { following common provisions con }\end{array}$ & $\begin{array}{l}\text { 1/1/2012 } \\
12: 00: 00 \mathrm{AM}\end{array}$ \\
\hline 94051021 & $\begin{array}{l}\text { Energy-related products marketed in the } \\
\text { European Union (EU) must comply with the } \\
\text { general labelling requirements laid down by }\end{array}$ & $\begin{array}{l}\text { 1/1/2012 } \\
12: 00: 00 \mathrm{AM}\end{array}$ \\
\hline
\end{tabular}




\begin{tabular}{|c|c|c|}
\hline & $\begin{array}{l}\text { Directive 2010/30/EU of the European } \\
\text { Parliament and of the Council (OJ L-153 } \\
\text { 18/06/2010) (CELEX 32010L0030) and with } \\
\text { the specific }\end{array}$ & \\
\hline 94049090 & $\begin{array}{l}\text { Textile products may only be placed on the } \\
\text { European Union (EU) market provided that they } \\
\text { are labelled, marked or accompanied with } \\
\text { commercial documents in compliance with } \\
\text { Regulation (EU) No } 1007 / 2011 \text { of the European } \\
\text { Parliament and of the Council (OJ L-272 }\end{array}$ & $\begin{array}{l}\text { 1/1/2012 } \\
12: 00: 00 \mathrm{AM}\end{array}$ \\
\hline 94021000 & $\begin{array}{l}\text { Labelling requirements are requested for } \\
\text { electrical and electronic equipment. }\end{array}$ & $\begin{array}{l}\text { 1/1/2012 } \\
\text { 12:00:00 AM }\end{array}$ \\
\hline 94021000 & $\begin{array}{l}\text { They are concerned with issues such as the } \\
\text { choice of materials, sterilisation, ergonomics, } \\
\text { safety warnings, labelling or instructions for } \\
\text { use. In particular the label must bear the } \\
\text { following particulars: a. The name and address } \\
\text { of the manufacturer; b. The }\end{array}$ & $\begin{array}{l}\text { 1/1/2012 } \\
\text { 12:00:00 AM }\end{array}$ \\
\hline 94029000 & $\begin{array}{l}\text { Particular procedure for systems and procedure } \\
\text { packs. Any natural or legal person who puts } \\
\text { devices bearing the CE marking together in } \\
\text { order to place them on the market as a system or } \\
\text { procedure pack, shall draw up a declaration } \\
\text { stating that: He has verifie }\end{array}$ & $\begin{array}{l}\text { 1/1/2012 } \\
\text { 12:00:00 AM }\end{array}$ \\
\hline 94021000 & $\begin{array}{l}\text { Before placing the EEE on the market, the } \\
\text { manufacturer must draw up the required } \\
\text { technical documentation and carry out the } \\
\text { internal production control procedure to ensure } \\
\text { compliance of the product with the } \\
\text { requirements laid down in the Directive. He } \\
\text { must }\end{array}$ & $\begin{array}{l}\text { 1/1/2012 } \\
\text { 12:00:00 AM }\end{array}$ \\
\hline 94049090 & $\begin{array}{l}\text { The General Product Safety Directive (GPSD) } \\
\text { establishes the following common provisions } \\
\text { concerning particularly: General safety } \\
\text { requirement: Producers are obliged to place } \\
\text { only safe products on the market. When the } \\
\text { manufacturer is not established in the E }\end{array}$ & $\begin{array}{l}\text { 1/1/2012 } \\
\text { 12:00:00 AM }\end{array}$ \\
\hline 94059900 & $\begin{array}{l}\text { In order to be placed in the European Union } \\
\text { (EU) market civil aircrafts must meet the } \\
\text { essential requirements of airworthiness laid } \\
\text { down by Regulation (EC) No } 216 / 2008 \text { of the } \\
\text { European Parliament and of the Council (OJ L- } \\
79 \text { 19/03/2008) (CELEX 32008R0216) an }\end{array}$ & $\begin{array}{l}\text { 1/1/2012 } \\
\text { 12:00:00 AM }\end{array}$ \\
\hline 94059900 & \multicolumn{2}{|c|}{$\begin{array}{l}\text { Provisions related to essential requirements, conformity assessment procedures, CE } \\
\text { and other information marks will not be compulsory for appliances which are } \\
\text { intended for incorporation into a given fixed installation but are otherwise not }\end{array}$} \\
\hline
\end{tabular}




\begin{tabular}{|c|c|c|}
\hline & \multicolumn{2}{|l|}{ commercially av } \\
\hline 94054035 & $\begin{array}{l}\text { Ecodesign requirements: The ecodesign } \\
\text { requirements are set out in Annex III to the } \\
\text { Regulation and are split into three parts: } \\
\text { Fluorescent lamps without integrated ballast } \\
\text { and high intensity discharge lamps Ballasts for } \\
\text { fluorescent lamps without integrated }\end{array}$ & $\begin{array}{l}1 / 1 / 2012 \\
12: 00: 00 \text { AM }\end{array}$ \\
\hline 94019080 & $\begin{array}{l}\text { The placing on the European Union (EU) } \\
\text { market of certain categories of motor vehicles } \\
\text { must comply with the technical requirements } \\
\text { which have been harmonised by EU legislation. } \\
\text { EU legislation has harmonised technical } \\
\text { requirements for three categories of mo }\end{array}$ & $\begin{array}{l}\text { 1/1/2012 } \\
\text { 12:00:00 AM }\end{array}$ \\
\hline 94051021 & $\begin{array}{l}\text { Conformity assessment: The conformity } \\
\text { assessment process is required to certify that } \\
\text { products comply with the essential requirements } \\
\text { referred to in Annex I. Compliance of apparatus } \\
\text { shall be demonstrated by means of the } \\
\text { procedures described in Annex II (In }\end{array}$ & $\begin{array}{l}\text { 1/1/2012 } \\
\text { 12:00:00 AM }\end{array}$ \\
\hline 94059900 & $\begin{array}{l}\text { Market surveillance: Each Member State } \\
\text { establishes authorities to be responsible for } \\
\text { checking that products placed on the market } \\
\text { meet the requirements of the applicable } \\
\text { directives and that the affixing and use of the } \\
\text { CE marking is correct. Market surveill }\end{array}$ & $\begin{array}{l}\text { 1/1/2012 } \\
\text { 12:00:00 AM }\end{array}$ \\
\hline 94011000 & $\begin{array}{l}\text { Depending on the nature of the product } \\
\text { (aircraft, part, appliance, etc) and the } \\
\text { requirement, compliance should be accredited } \\
\text { by different specific certificates and/or licenses } \\
\text { which are established in Commission } \\
\text { Regulation (EU) No 748/2012 (OJ L-224 21/08 }\end{array}$ & $\begin{array}{l}1 / 1 / 2012 \\
12: 00: 00 \mathrm{AM}\end{array}$ \\
\hline 94029000 & $\begin{array}{l}\text { This measure is related to CE marking } \\
\text { requirement (considered as a certification } \\
\text { requirement). CE marking: Devices considered } \\
\text { to meet the essential requirements must bear the } \\
\text { CE marking of conformity when they are placed } \\
\text { on the market. It must appear in a }\end{array}$ & $\begin{array}{l}\text { 1/1/2012 } \\
\text { 12:00:00 AM }\end{array}$ \\
\hline 94019030 & $\begin{array}{l}\text { EC Type-approval procedure: Applications for } \\
\text { type-approval must be submitted by the } \\
\text { manufacturer or his authorised representative to } \\
\text { the approval authority within a single Member } \\
\text { State. These must be accompanied by the } \\
\text { manufacturer's dossier and the type- }\end{array}$ & $\begin{array}{l}1 / 1 / 2012 \\
12: 00: 00 \text { AM }\end{array}$ \\
\hline 94060020 & $\begin{array}{l}\text {-A FLEGT licence according to Council } \\
\text { Regulation (EC) } 2173 / 2005 \text { on the } \\
\text { establishment of a FLEGT licensing scheme for }\end{array}$ & $\begin{array}{l}\text { 1/1/2013 } \\
\text { 12:00:00 AM }\end{array}$ \\
\hline
\end{tabular}




\begin{tabular}{|c|c|c|}
\hline & $\begin{array}{l}\text { imports of timber into the European Community } \\
\text { (OJ L-347 30/12/2005)(CELEX 32005R2173). } \\
\text { Note: this licensing scheme will not be } \\
\text { applicable }\end{array}$ & \\
\hline 94021000 & $\begin{array}{l}\text { Importers and distributors must ensure that } \\
\text { manufacturers have met their obligations and } \\
\text { that only compliant products are placed on the } \\
\text { EU market. }\end{array}$ & $\begin{array}{l}\text { 1/1/2013 } \\
\text { 12:00:00 AM }\end{array}$ \\
\hline 94029000 & $\begin{array}{l}\text { Technical file: The manufacturer (or his } \\
\text { authorised representative established in the EU) } \\
\text { must compile all the relevant technical } \\
\text { documentation to demonstrate the conformity of } \\
\text { the product to the essential requirements. This } \\
\text { file must be kept available fo }\end{array}$ & $\begin{array}{l}\text { 1/1/2012 } \\
12: 00: 00 \text { AM }\end{array}$ \\
\hline 44011000 & $\begin{array}{l}\text {-A FLEGT licence according to Council } \\
\text { Regulation (EC) } 2173 / 2005 \text { on the } \\
\text { establishment of a FLEGT licensing scheme for } \\
\text { imports of timber into the European Community } \\
\text { (OJ L-347 30/12/2005)(CELEX 32005R2173). } \\
\text { Note: this licensing scheme will not be } \\
\text { applicable }\end{array}$ & $\begin{array}{l}\text { 1/1/2013 } \\
12: 00: 00 \text { AM }\end{array}$ \\
\hline 94060020 & $\begin{array}{l}\text { Import bans Member States shall ban the } \\
\text { introduction into their territory of: Certain } \\
\text { particularly dangerous harmful organisms, } \\
\text { which are listed in Annex I, Part A to Council } \\
\text { Directive 2000/29/EC. Plants and plant products } \\
\text { listed in Annex II, Part A, wher }\end{array}$ & $\begin{array}{l}1 / 1 / 2012 \\
12: 00: 00 \text { AM }\end{array}$ \\
\hline 94060020 & $\begin{array}{l}\text { Customs inspection and plant health checks. In } \\
\text { addition to the above mentioned certificates, the } \\
\text { plants and plant products listed in Annex V, } \\
\text { Part B to Council Directive 2000/29/EC shall, } \\
\text { from the time of their entry in the EU, be } \\
\text { subject to customs inspe }\end{array}$ & $\begin{array}{l}\text { 1/1/2012 } \\
12: 00: 00 \mathrm{AM}\end{array}$ \\
\hline
\end{tabular}

